\title{
The Aggregate Demand for Treasury Debt
}

\author{
Krishnamurthy, Arvind; Vissing-Jorgensen, Annette
}

Document Version

Final published version

Published in:

Journal of Political Economy

DOI:

$10.1086 / 666526$

Publication date:

2012

License

Unspecified

Citation for published version (APA):

Krishnamurthy, A., \& Vissing-Jorgensen, A. (2012). The Aggregate Demand for Treasury Debt. Journal of Political Economy, 120(2), 233-267. https://doi.org/10.1086/666526

Link to publication in CBS Research Portal

\section{General rights}

Copyright and moral rights for the publications made accessible in the public portal are retained by the authors and/or other copyright owners and it is a condition of accessing publications that users recognise and abide by the legal requirements associated with these rights.

Take down policy

If you believe that this document breaches copyright please contact us (research.lib@cbs.dk) providing details, and we will remove access to the work immediately and investigate your claim. 


\section{CHICAGO JOURNALS}

The Aggregate Demand for Treasury Debt

Author(s): Arvind Krishnamurthy and Annette Vissing-Jorgensen

Reviewed work(s):

Source: Journal of Political Economy, Vol. 120, No. 2 (April 2012), pp. 233-267

Published by: The University of Chicago Press

Stable URL: http://www.jstor.org/stable/10.1086/666526

Accessed: 01/01/2013 11:09

Your use of the JSTOR archive indicates your acceptance of the Terms \& Conditions of Use, available at http://www.jstor.org/page/info/about/policies/terms.jsp

JSTOR is a not-for-profit service that helps scholars, researchers, and students discover, use, and build upon a wide range of content in a trusted digital archive. We use information technology and tools to increase productivity and facilitate new forms of scholarship. For more information about JSTOR, please contact support@jstor.org.

The University of Chicago Press is collaborating with JSTOR to digitize, preserve and extend access to Journal of Political Economy. 


\title{
The Aggregate Demand for Treasury Debt
}

\author{
Arvind Krishnamurthy
}

Northwestern University and National Bureau of Economic Research

\section{Annette Vissing-Jorgensen}

Northwestern University, National Bureau of Economic Research, and Centre for Economic Policy Research

\begin{abstract}
Investors value the liquidity and safety of US Treasuries. We document this by showing that changes in Treasury supply have large effects on a variety of yield spreads. As a result, Treasury yields are reduced by 73 basis points, on average, from 1926 to 2008 . Both the liquidity and safety attributes of Treasuries are driving this phenomenon. We document this by analyzing the spread between assets with different liquidity (but similar safety) and those with different safety (but similar liquidity). The low yield on Treasuries due to their extreme safety and liquidity suggests that Treasuries in important respects are similar to money.
\end{abstract}

We thank many colleagues and participants at talks at University of California, Los Angeles, University of Chicago, Columbia University, Dartmouth, Michigan State University, University of Michigan, Massachusetts Institute of Technology, Northwestern University, Princeton University, Queen's University, University of Texas-Austin, University of South Carolina, Yale University, Board of Governors of the Federal Reserve, the Federal Reserve Bank of New York, NBER Asset Pricing meeting, NBER Monetary Economics meeting, NBER Economic Fluctuations and Growth meeting, Western Finance Association, Duke-University of North Carolina Asset Pricing conference, University of Michigan Mitsui Life Symposium on Financial Markets, London School of Economics-Paul Woolley Centre conference, Moody's Analytics, University of British Columbia Winter Finance Conference, and Department of the Treasury for comments. Josh Davis, Chang Joo Lee, and Byron Scott provided research assistance. We thank Moody's Analytics (formerly Moody's KMV) for providing its expected default frequency credit measure, Michael Fleming and Kenneth Kuttner for data on P2-rated commercial paper, and Henning Bohn for debt/GDP data. 


\section{Introduction}

Money, such as currency or checking accounts, offers a low rate of return relative to other assets. The reasons behind this phenomenon are well understood. Money is a medium of exchange for buying goods and services, has high liquidity, and has extremely high safety in the sense of offering absolute security of nominal repayment. Investors value these attributes of money and drive down the yield on money relative to other assets.

We argue that a similar phenomenon affects the prices of Treasury bonds. The high liquidity and safety of Treasuries drive down the yield on Treasuries relative to assets that do not to the same extent share these attributes. Figure 1 provides evidence for this assertion. The figure graphs the yield spread between Aaa-rated corporate bonds and Treasury securities against the US government debt-to-GDP ratio (i.e., the ratio of the market value of publicly held US government debt to US GDP). The figure reflects a Treasury demand function, akin to a money demand function. When the supply of Treasuries is low, the value that

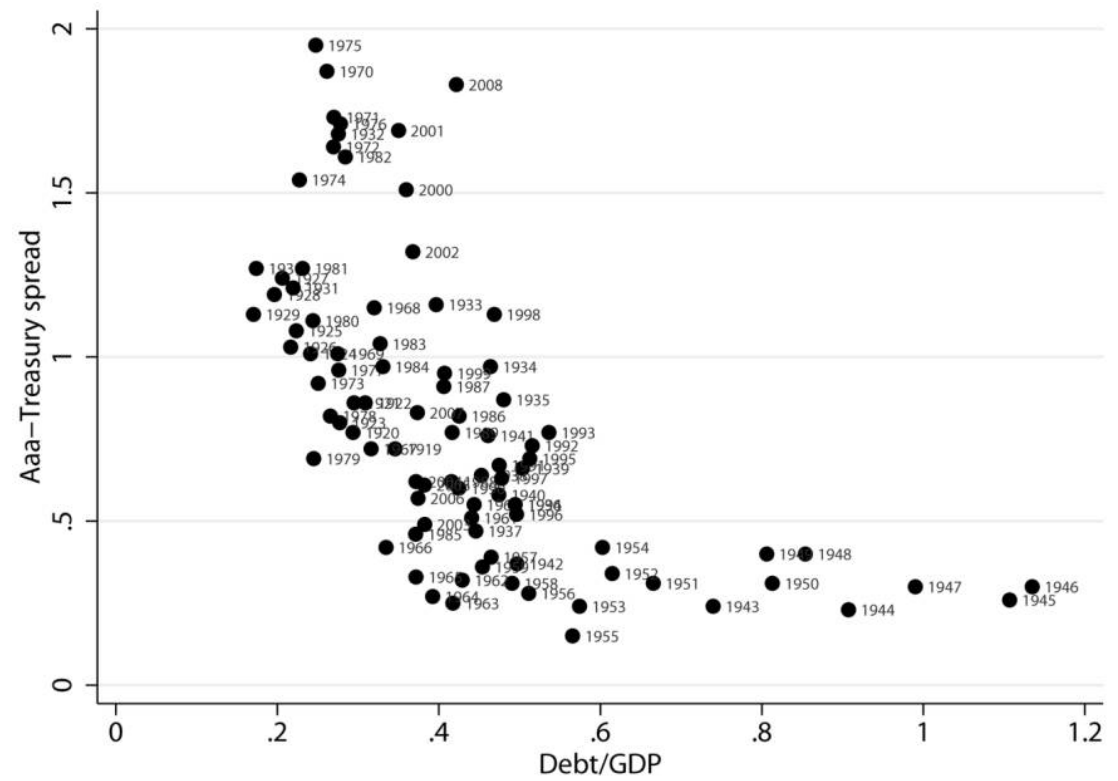

FIG. 1.-Corporate bond spread and government debt. The figure plots the Aaa-Treasury corporate bond spread ( $y$ axis) against the debt-to-GDP ratio ( $x$ axis) on the basis of annual observations from 1919 to 2008. The corporate bond spread is the difference between the percentage yield on Moody's Aaa long-maturity bond index and the percentage yield on long-maturity Treasury bonds. 
investors assign to the liquidity and safety attributes offered by Treasuries (referred to below as the Treasury convenience yield) is high. As a result, the yield on Treasuries is low relative to the yield on the Aaa corporate bonds, which offer less liquidity and safety. The opposite applies when the supply of Treasuries is high. We present detailed econometric evidence of the relation reflected in figure 1 using several alternative yield spread measures and controlling for corporate bond default risk.

We further show that it is the liquidity and safety attributes of Treasuries that drive investors' high valuation of Treasuries. We examine the yield spread between a pair of assets that are different only in terms of their liquidity, as well as the yield spread between a pair of assets that are different only in terms of their safety. Under the hypothesis that liquidity and safety are priced attributes, the yield spread between these pairs of assets should reflect the equilibrium price of liquidity/safety. We show that changes in Treasury supply affect each of these yield spreads. The results indicate that Treasuries offer liquidity and safety so that changes in the supply of Treasuries separately change the equilibrium prices of liquidity and safety.

We compute that the value investors have paid on average over our main sample for 1926-2008 for the liquidity and safety attributes of Treasuries is 73 basis points per year, of which at most 46 basis points are for liquidity and at least 27 basis points for safety. Our findings imply that the government collects seigniorage from the liquidity and safety attributes of Treasuries, and we compute that the government has saved interest costs of about 0.25 percent of GDP per year because of investors' demand for Treasuries. This figure is comparable in magnitude to the traditional notion of seigniorage, which stems from the public's willingness to hold fiat money at zero interest. We compute that the latter seigniorage is also around 0.25 percent of GDP per year. Our results also indicate that Treasury interest rates are not an appropriate benchmark for "riskless" rates. Cost of capital computations using the capital asset pricing model should use a higher riskless rate than the Treasury rate; a company with a beta of zero cannot raise funds at the Treasury rate. In addition, the equity premium measured relative to Treasury rates will partly be driven by the liquidity and safety of Treasuries.

Relation to literature.-Longstaff, Mithal, and Neis (2005) use default risk as estimated from the price of credit default swaps to measure the component of the spread between corporate and Treasury yields that is due to default considerations. They find a large unexplained nondefault component. This finding is in keeping with many papers in the corporate bond pricing literature. Compared to the prior literature, the novelty of our work is to offer more direct evidence of the existence of a nondefault component by documenting that the amount of Treasuries outstanding is a key driver of the nondefault component of the cor- 
porate bond spread. Furthermore, our paper shows that the nondefault component is driven by the liquidity and safety attributes of Treasury bonds.

We are aware of only a few papers in the literature that have noted a relation between the supply of government debt and interest rate spreads. Cortes (2003) documents a relation between Treasury supply and swap spreads over the period 1994-2003. Longstaff (2004) documents a relation between the supply of Treasury debt and the spread between Refcorp bonds and Treasury bonds over the period 1991-2001. Relative to these papers, we study a much longer sample, provide a theoretical basis to study the relation, use several approaches to rule out that the relation could be driven by time-varying default risk, and decompose the Treasury convenience yield into a liquidity and safety component.

There is also a literature that seeks to examine whether the relative supplies of long- and short-term Treasury debt have an effect on the term structure of Treasury yields. Early work in this literature was motivated by the 1962-64 "operation twist," in which the government tried to flatten the term structure by shortening the average maturity of government debt (see, e.g., Modigliani and Sutch 1966). More recently, Reinhart and Sack (2000) show that the projected government deficit is positively related to the slope of the Treasury yield curve, suggesting that this is evidence of a supply effect. More systematic evidence of a relative supply effect is provided by Greenwood and Vayanos (2010), who examine data for 1952-2005 and show that the relative supply of long and short Treasuries is related to the slope of the yield curve. Krishnamurthy and Vissing-Jorgensen (2011) study the Federal Reserve quantitative easing policies in 2008-11 whereby the supply of long-term Treasuries was reduced. Using an event study methodology, they show that long-term Treasury yields fell relative to short-term yields and attribute this to demand for extremely safe assets of specific maturities. These papers suggest that supply effects affect the relative yields of long and short Treasuries and are complementary to our study.

In macroeconomics, there is a large literature exploring the Ricardian equivalence proposition (Barro 1974), that the financing choices of the government used to fund a given stream of government expenditures are irrelevant for equilibrium quantities and prices. One implication of the Ricardian equivalence proposition is that the size of government debt has no causal effect on interest rates. Despite a large amount of research devoted to studying this topic, there is yet no clear consensus on the effects of debt on interest rates (see, e.g., the survey by Elmendorf and Mankiw [1999]). We identify an effect on the spread between government interest rates and corporate interest rates. It is possible that Ricardian equivalence fails in a way in which government debt has an 
effect on the general level of interest rates, both corporate and government. Since we focus on spreads, we are unable to isolate such an effect. From an empirical standpoint, the advantage of focusing on spreads rather than on the level of interest rates is that the spread measure is unaffected by other shocks (such as changes in expected inflation) that affect the level of interest rates and complicate inference. We also bypass endogeneity issues stemming from government behavior since it is unlikely that the government chooses debt levels on the basis of the corporate bond spread.

This paper is laid out as follows. Section II lays out a theoretical framework to relate the demand for the attributes offered by Treasuries to the price of Treasuries relative to other assets. The section develops a series of predictions of the theory. We test each of the theoretical predictions in Section III. The paper also includes appendices providing details on the data construction and the mathematical derivations.

\section{Theoretical Framework}

We articulate our theory by modifying a standard representative agent asset-pricing model to include a term whereby agents derive utility directly from holdings of a "convenience" asset. The modification is along the lines of Sidrauski (1967), which considers a model in which agents derive utility from their holdings of money. The representative agent maximizes

$$
E \sum_{t=1}^{\infty} \beta^{t} u\left(C_{t}\right) .
$$

Suppose that $C_{t}$ is the sum of an endowment of $c_{t}$ plus "convenience" benefits:

$$
C_{t}=c_{t}+\nu\left(\theta_{t}^{A}, \mathrm{GDP}_{t} ; \xi_{t}\right) .
$$

The benefits are a function of the real holdings of convenience assets, $\theta_{t}^{A}$. One example that we elaborate on below is that the function $\nu(\cdot)$ captures the notion that holding more Treasury securities reduces costs that would otherwise be incurred by transacting in a less liquid security such as corporate bonds. ${ }^{1}$ The argument $\theta_{t}^{A}$ is the market value of the agent's real holdings of convenience assets, which include both Treasuries, $\theta_{t}^{T}$, and any other private-sector assets, $\theta_{t}^{P}$, that provide services similar to Treasuries:

\footnotetext{
1 To be more precise, we can define $C_{t}=c_{t}-\operatorname{cost}\left(\theta_{t}^{A}, \mathrm{GDP}_{t} ; \xi_{t}\right)$, where the function $\operatorname{cost}(\cdot)$ reflects costs that will be incurred by holding less liquid securities. When more Treasuries are held, these costs are reduced. This is just a renormalization relative to our defining a benefit function $\nu(\cdot)$ that is increasing in $\theta_{t}^{A}$. The important aspect of the modeling is that $d C_{t} / d \theta_{t}^{A}>0$.
} 


$$
\theta_{t}^{A}=\theta_{t}^{T}+k^{P} \theta_{t}^{P} .
$$

The constant $k^{P}$ measures the convenience services provided by the private-sector assets relative to Treasuries. The term $\xi_{t}$ in the convenience function is a preference shock that affects how much utility is derived from convenience assets. An example of such a shock is a "flight to quality" as during a financial crisis, where investors may temporarily increase their valuation of convenience assets such as Treasuries. The income of the agent is $\mathrm{GDP}_{t}$, which is measured in real terms.

We assume that the convenience function is homogeneous of degree one in $\mathrm{GDP}_{t}$ and $\theta_{t}^{A}$. This captures the idea that liquidity benefits double if both income and convenience assets double. Thus define

$$
v\left(\frac{\theta_{t}^{A}}{\mathrm{GDP}_{t}} ; \xi_{t}\right) \mathrm{GDP}_{t} \equiv \nu\left(\theta_{t}^{A}, \mathrm{GDP}_{t} ; \xi_{t}\right)
$$

We assume that the convenience function is increasing in $\theta_{t}^{A} / \mathrm{GDP}_{t}$, but the marginal convenience benefit is decreasing in $\theta_{t}^{A} / \mathrm{GDP}_{t}$ and has the property $\lim _{\theta_{t}^{A} / \mathrm{GDP}_{t} \rightarrow \infty} v^{\prime}\left(\theta_{t}^{A} / \mathrm{GDP}_{t} ; \xi_{t}\right)=0$. That is, holding more convenience assets reduces the marginal value of an extra unit of convenience assets. Furthermore, this marginal value approaches zero if the agent is holding a large amount of convenience assets.

Let us next consider what underlies our reduced-form convenience function $v(\cdot)$. We argue that Treasuries are valued for their liquidity and safety. Papers such as Vayanos and Vila (1999) and Rocheteau (2009) show how the superior liquidity of an asset will lead investors to pay a higher price for that asset. Under these theories, an increase in the holding of liquid assets will lower the marginal liquidity service provided by any liquid asset. That is, our earlier assumption that the marginal convenience, $v^{\prime}(\cdot)$, is decreasing in $\theta_{t}^{A} / \mathrm{GDP}_{t}$ is a natural outcome of these models. We refer to these theories as describing a liquidity attribute.

A second benefit of Treasuries is that they are widely believed to provide absolute certainty of nominal repayment. Under some theories, this safety attribute can drive a convenience yield that is declining in the supply of safe assets.

Consider short-term Treasuries, such as 3- or 6-month maturity bills, which carry negligible price risk. Suppose that some investors face costs of understanding investment in risky assets, as in the literature on limited participation of investors in the stock market (Vissing-Jorgensen 2003). These investors will have a unique demand for riskless assets, driving up the price of riskless assets. In addition, in many limited participation models, expanding the stock of riskless assets reduces risk premia and raises riskless rates (see Gomes and Michaelides 2008). Another explanation for safety demand stems from the use of Treasuries as collateral in many financial transactions. Gorton (2010) notes that there is a substantial demand for collateral for purposes of mitigating counterparty 
risk in derivatives and settlement systems. The collateral in these transactions is required to be extremely safe, thus also driving the demand for a safety attribute. Bansal and Coleman (1996) argue that commercial banks and money market funds use Treasuries to back checkable deposits. Treasuries thus inherit some of the medium of exchange convenience of money, lowering the yield on Treasuries. In this explanation, it is again the safety of Treasuries that makes them good backing for checking accounts. We will offer empirical evidence that the safety attribute of Treasuries is one of the drivers of the convenience yield. However, we will not distinguish further whether the underlying driver of safety demand is due to limited participation, collateral, or the checkbacking explanations.

The safety explanation for low Treasury yields is distinct from that suggested by any of the standard representative agent model explanations of high risk premia in asset markets. This literature has demonstrated how altering the preferences of a representative agent to feature high risk aversion can produce low riskless interest rates and high risk premia. Thus, in the representative agent model there will be a negative relation between the price of a bond and its default risk. However, the quantity of convenience assets is unrelated to asset prices in the representative agent model. A way to think about how safety demand works is that the relation between price and default risk is very steep near zero default risk, over and above the negative relation implied by the representative agent model. Furthermore, the slope of this curve near zero default risk decreases in Treasury supply. This latter prediction generates a negative relation between the corporate Treasury bond spread and Treasury supply (at a given level of corporate bond default risk) and is how to distinguish the safety explanation from a standard risk-based explanation (fig. 1 in Krishnamurthy and Vissing-Jorgensen [2011] illustrates this relation).

The safety attribute may also apply to long-term Treasuries, such as 30-year bonds, which carry significant price risk because of interest rate volatility. Here, the limited participation, collateral usage, or check-backing explanations are unlikely to be relevant. Instead, Greenwood and Vayanos (2010) suggest that investors such as defined-benefit pension funds have a special demand for certain long-term payoffs to back longterm nominal obligations. The same motive may apply to insurance companies that write long-term policies. Furthermore, Chalmers (1998) describes how long-term Treasury bonds are posted as collateral by municipalities to secure their own long-term borrowings. Broadly, this explanation is similar to the preferred habitat hypothesis of the term structure of interest rates (Modigliani and Sutch 1966), under which investors are hypothesized to prefer certain maturities of bonds, but 
applied only (or to a larger extent) to extremely safe bonds. We refer to these theories as describing a long-term safety attribute.

We can represent these different theoretical rationales for convenience in our specification of $v(\cdot)$. Denote $\theta_{t}^{T \text { long }}$ as the stock of longterm Treasury bonds and $\theta_{t}^{T \text { short }}$ as the stock of short-term Treasuries $\left(\theta_{t}^{T}=\theta_{t}^{T \text { long }}+\theta_{t}^{T \text {,short }}\right)$. Also define $\theta_{t}^{P \text { liq }}$ as the stock of non-Treasury liquid assets, $\theta_{t}^{P \text { short-safe }}$ as the stock of non-Treasury short-term safe assets, and $\theta_{t}^{P \text {,long-safe }}$ as the stock of non-Treasury long-term safe assets. Suppose that total convenience on short-term Treasuries can be written as the sum of two convenience components:

$$
\begin{aligned}
v_{T \text {,short }}(\cdot)= & v_{\text {liq }}\left(\frac{\theta_{t}^{T}+k^{\text {liq }} \theta_{t}^{P \text {,liq }}}{\mathrm{GDP}_{t}} ; \xi_{t}^{\text {liq }}\right) \\
& +v_{\text {short-safe }}\left(\frac{\theta_{t}^{T \text {,short }}+k^{\text {short-safe }} \theta_{t}^{P \text {,short-safe }}}{\mathrm{GDP}_{t}} ; \xi_{t}^{\text {short-safe }}\right) .
\end{aligned}
$$

Similarly, we can specify the convenience on long-term Treasuries as

$$
\begin{aligned}
v_{T, \text { long }}(\cdot)= & v_{\text {liq }}\left(\frac{\theta_{t}^{T}+k^{\text {liq }} \theta_{t}^{P \text {,liq }}}{\operatorname{GDP}_{t}} ; \xi_{t}^{\text {liq }}\right) \\
& +v_{\text {long-safe }}\left(\frac{\theta_{t}^{T \text { long }}+k^{\text {long-safe }} \theta_{t}^{P \text {,long-safe }}}{\mathrm{GDP}_{t}} ; \xi_{t}^{\text {long-safe }}\right) .
\end{aligned}
$$

The constants, $k^{\text {liq }}, k^{\text {short-safe }}$, and $k^{\text {long-safe }}$, measure the convenience that the private-sector assets offer relative to Treasuries.

Our specification emphasizes that the safety attributes may differ across short- and long-term assets and thus lead to a difference in convenience value in long-term assets relative to short-term assets. In contrast, our specification assumes that both long- and short-term Treasuries offer equal liquidity services. The empirical literature has documented the existence of significant liquidity premia on both long-term and shortterm Treasuries (Amihud and Mendelson 1991; Krishnamurthy 2002; Longstaff 2004). Consistent with the results from Longstaff, who studies liquidity premia on both long-term and short-term (3 months and longer) Treasuries, we make the assumption that long- and short-term Treasuries are equally liquid.

\section{A. Spreads and Supply}

We derive pricing expressions for short- and long-term bonds based on these different specifications of convenience. As we describe below, decomposing the convenience in the manner above also yields empirical tests of the existence of priced safety and liquidity attributes. Before describing these tests, let us turn to asset pricing. We initially derive predictions of the convenience yield theory that do not distinguish be- 
tween the liquidity and safety motives. We then turn to predictions implied by each of these separate motives. In terms of the framework above, our initial set of predictions implicitly assume that both $v_{T, \text { long }}$ and $v_{T \text {,short }}$ are functions only of $\theta_{t}^{T}$ (as opposed to functions of both total Treasury supply and short- or long-term Treasury supply). This will be the case if long and short Treasury supply moves in parallel (and if the demand shocks are perfectly correlated) or if only a liquidity motive is present. We relax this assumption later.

Denote the price level at date $t$ as $Q_{t}$. If the agent buys a zero-coupon nominal Treasury bond for a nominal price $P_{t}^{T}$, his real holdings $\theta_{t}^{A}$ rise by $P_{t}^{T} / Q_{t}{ }^{2}$ The first-order condition for Treasury bond holdings is then

$$
-\frac{P_{t}^{T}}{Q_{t}} u^{\prime}\left(C_{t}\right)+\beta E_{t}\left[\frac{P_{t+1}^{T}}{Q_{t+1}} u^{\prime}\left(C_{t+1}\right)\right]+\frac{P_{t}^{T}}{Q_{t}} v^{\prime}\left(\theta_{t}^{A} / \operatorname{GDP}_{t}, \xi_{t}\right) u^{\prime}\left(C_{t}\right)=0 .
$$

Define the pricing kernel for nominal payoffs as

$$
M_{t+1}=\beta \frac{u^{\prime}\left(C_{t+1}\right)}{u^{\prime}\left(C_{t}\right)} \frac{Q_{t}}{Q_{t+1}}
$$

so that

$$
\begin{aligned}
P_{t}^{T} & =E_{t}\left[M_{t+1} P_{t+1}^{T}\right]+P_{t}^{T}{v^{\prime}}^{\prime}\left(\theta_{t}^{A} / \mathrm{GDP}_{t} ; \xi_{t}\right) \Rightarrow \\
P_{t}^{T} & =\frac{E_{t}\left[M_{t+1} P_{t+1}^{T}\right]}{1-v^{\prime}\left(\theta_{t}^{A} / \mathrm{GDP}_{t} ; \xi_{t}\right)} .
\end{aligned}
$$

This expression indicates that a positive marginal value of convenience, $v^{\prime}(\cdot)$, raises the price of Treasuries, $P_{t}^{T}$.

Let us next derive pricing expressions for a zero-coupon corporate bond that offers no convenience services. Suppose that the corporate bond may default next period with probability $\lambda_{t}$ and in default pays $1-L_{t+1}$, where $L_{t+1}$ measures the amount of losses suffered in default (and is a random variable). If the bond does not default, it is worth $P_{t+1}^{C}$. Then, since the bond offers no convenience, its price satisfies

$$
\begin{aligned}
P_{t}^{C}= & \lambda_{t} E_{t}\left[M_{t+1}\left(1-L_{t+1}\right) \mid \text { Default }\right] \\
& +\left(1-\lambda_{t}\right) E_{t}\left[M_{t+1} P_{t+1}^{C} \mid \text { No Default }\right] .
\end{aligned}
$$

In our empirical work we estimate the convenience demand $v^{\prime}(\cdot)$ by relating $\theta_{t}^{T}$ to two different measures of the price difference between $P_{t}^{C}$ and $P_{t}^{T}$, short-maturity yield spreads between corporate and Treasury bonds and long-maturity yield spreads. We now derive expressions for each of these price measures and compare them. For simplicity, we focus our derivations on continuously compounded yields.

\footnotetext{
${ }^{2}$ We derive pricing expressions for zero-coupon Treasury and corporate bonds. In our empirical work, we examine coupon bonds and assume that the impact of Treasury supply on coupon bond spreads is qualitatively similar.
} 
Consider first the case of one-period bonds. For such bonds, $P_{t+1}^{C}=$ $P_{t+1}^{T}=1$. Then

$$
e^{-i_{t}^{T}}=P_{t}^{T}=\frac{E_{t}\left[M_{t+1} P_{t+1}^{T}\right]}{1-v^{\prime}\left(\theta_{t}^{A} / \mathrm{GDP}_{t} ; \xi_{t}\right)} \approx e^{v^{\prime}\left(\theta_{t}^{A} / \mathrm{GDP}_{i} \xi_{t}\right)} E_{t}\left[M_{t+1}\right] .
$$

For the corporate bond, define $\tilde{L}_{t+1}$ as a random variable that is equal to zero if there is no default and equal to $L_{t+1}$ if there is default. Then

$$
\begin{aligned}
e^{-i_{t}^{C}}=P_{t}^{C} & =E_{t}\left[M_{t+1}\right]-E_{t}\left[M_{t+1}\right] E_{t}\left[\tilde{L}_{t+1}\right]-\operatorname{Cov}_{t}\left[M_{t+1}, \tilde{L}_{t+1}\right] \\
& \approx e^{-\lambda_{t} E_{t}\left[L_{t+1}\right]-\operatorname{Cov}_{t}\left[M_{t+1}, \tilde{L}_{t+1}\right] / E_{t}\left[M_{t+1}\right]} E_{t}\left[M_{t+1}\right] .
\end{aligned}
$$

We thus have the following prediction.

Prediction 1 (Impact of Treasury supply on short-term spreads). The one-period yield spread between corporate and Treasury bonds is related to the stock of Treasuries as follows:

$$
\begin{aligned}
S_{t, 1} \equiv i_{t}^{C}-i_{t}^{T}= & v^{\prime}\left(\frac{\theta_{t}^{T}+k^{P} \theta_{t}^{P}}{\operatorname{GDP}_{t}} ; \xi_{t}\right)+\lambda_{t} E_{t}\left[L_{t+1}\right] \\
& +\operatorname{Cov}_{t}\left[M_{t+1}, \tilde{L}_{t+1}\right] / E_{t}\left[M_{t+1}\right] .
\end{aligned}
$$

The yield spread reflects the sum of three terms: the convenience yield on Treasuries, the expected default on the corporate bond, and a risk premium associated with the covariance between default and the pricing kernel. Assuming that $v^{\prime \prime}(\cdot)<0, S_{t, 1}$ is declining in $\left(\theta_{t}^{T}+k^{P} \theta_{t}^{P}\right) / \mathrm{GDP}_{t}$. Consider next the relationship between $S_{t, 1}$ and $\theta_{t}^{T} / \mathrm{GDP}_{t}$. Project $\theta_{t}^{P} / \mathrm{GDP}_{t}$ linearly on $\theta_{t}^{T} / \mathrm{GDP}_{t}$, so that $\theta_{t}^{P} / \mathrm{GDP}_{t}=a_{0}+a_{1} \theta_{t}^{T} / \mathrm{GDP}_{t}+$ error $_{t}$, where the error ${ }_{t}$ is uncorrelated with $\theta_{t}^{T} / \mathrm{GDP}_{t}$. Then

$$
\left(\theta_{t}^{T}+k^{P} \theta_{t}^{P}\right) / \mathrm{GDP}_{t}=k^{P} a_{0}+\left(1+k^{P} a_{1}\right) \theta_{t}^{T} / \mathrm{GDP}_{t}+k^{P} \text { error }_{t} .
$$

If $1+k^{P} a_{1}>0$, then $S_{t, 1}$ is declining in $\theta_{t}^{T} / \mathrm{GDP}_{t}$. The latter condition will be satisfied if $a_{1}>-1 / k^{P}$, that is, unless the private sector reduces its supply of substitutes by more (in effective terms, $k^{P} \theta_{t}^{P} / \mathrm{GDP}_{t}$ ) than the increase in the Treasury supply.

We verify the prediction of the convenience model that an increase in $\theta_{t}^{T} / \mathrm{GDP}_{t}$ causes the yield spread to fall. Our regressions of the yield spread on $\theta_{t}^{T} / \mathrm{GDP}_{t}$ recover $v^{\prime}(\cdot)\left\{1+k^{P}\left[\partial\left(\theta_{t}^{P} / \mathrm{GDP}_{t}\right) / \partial\left(\theta_{t}^{T} / \mathrm{GDP}_{t}\right)\right]\right\}$ rather than $v^{\prime}(\cdot)$ because of the private-sector reaction to changes in Treasury supply. In order to recover $v^{\prime}(\cdot)$, we further need knowledge of $k^{P}$ and $\partial\left(\theta_{t}^{P} / \mathrm{GDP}_{t}\right) / \partial\left(\theta_{t}^{T} / \mathrm{GDP}_{t}\right)$. We do not explore that in this paper because for most questions of interest, it is more important to know $v^{\prime}(\cdot)\{1+$ $\left.k^{P}\left[\partial\left(\theta_{t}^{P} / \mathrm{GDP}_{t}\right) / \partial\left(\theta_{t}^{T} / \mathrm{GDP}_{t}\right)\right]\right\}$ rather than $v^{\prime}(\cdot)$.

Note that it is possible that Treasury supply reacts accommodating to demand shocks $\left(\xi_{t}\right)$ or to increases in corporate default risk. This will bias the relation between spreads and Treasury supply toward finding a positive relation, the opposite of the causal negative relation from 
Treasury supply to spreads. However, we view it as unlikely that overall Treasury supply reacts substantially to demand shocks or changes in the risk of corporate bonds. The more plausible reaction involves the private-sector supply or the government's supply of particular maturities.

Let us next consider multiperiod bonds. Define the $\tau$-period yields on corporate and Treasury bonds as

$$
i_{t, \tau}^{T}=-\frac{1}{\tau} \ln P_{t}^{T} \quad \text { and } \quad i_{t, \tau}^{C}=-\frac{1}{\tau} \ln P_{t}^{C} .
$$

The spread between these bonds is $S_{t, \tau}=i_{t, \tau}^{C}-i_{t, \tau}^{T}$.

Consider again the derivation for corporate bonds. Our derivation for multiperiod bonds closely follows Duffie and Singleton (1999), reflecting the standard practice in the corporate bond pricing literature. Suppose that the event of default or no default is nonsystematic (i.e., uncorrelated with $\left.M_{t+1}\right)$. Then, we can drop the conditioning on default/no default and rewrite (10) as

$$
P_{t}^{C}=E_{t}\left[M_{t+1}\left(\lambda_{t}\left(1-L_{t+1}\right)+\left(1-\lambda_{t}\right) P_{t+1}^{C}\right)\right] .
$$

Assume that we can write the expected present value of the payment in default as

$$
E_{t}\left[M_{t+1}\left(1-L_{t+1}\right)\right]=E_{t}\left[M_{t+1} P_{t+1}^{C}\right]\left(1-D_{t}\right)
$$

for a suitable process $D_{t}{ }^{3}$ This is Duffie and Singleton's "recovery of market value" assumption. Then

$$
P_{t}^{C}=\left[\lambda_{t}\left(1-D_{t}\right)+\left(1-\lambda_{t}\right)\right] E_{t}\left[M_{t+1} P_{t+1}^{C}\right] \approx e^{-\lambda_{t} D_{t}} E_{t}\left[M_{t+1} P_{t+1}^{C}\right] .
$$

Note that the term $P_{t+1}^{C}$ is a function of $D_{t+1}$ and $\lambda_{t+1}$, which embody changes in future default expectations such as downgrades. For highgrade corporate bonds, which are the focus of our study, almost all of the default-related risk is of this form rather than in terms of the bonds defaulting between $t$ and $t+1$. In our setup, the latter default-related risk may be correlated with $M_{t+1}$ and carry a risk premium. Thus, our restriction that the default event in the next period is nonsystematic is not a substantively important restriction but does help to simplify our pricing expressions.

Prediction 2 (Impact of Treasury supply on long-term spreads). The yield spread between $\tau$-period corporate and Treasury bonds is related to the stock of Treasuries as follows:

\footnotetext{
${ }^{3}$ Note that in expression (15), the left-hand-side expectation is conditioning on default, whereas the right-hand-side expectation is conditioning on no default. However, given the assumption that the default event is nonsystematic, we can drop the conditioning.
} 


$$
\begin{aligned}
S_{t, \tau}= & \sum_{j=t}^{t+\tau-1} \frac{1}{\tau} E_{t}\left[v^{\prime}\left(\theta_{j}^{A} / \mathrm{GDP}_{j} ; \xi_{j}\right)\right]+\sum_{j=t}^{t+\tau-1} \frac{1}{\tau} E_{t}\left[\lambda_{j} D_{j}\right] \\
& -\sum_{j=t}^{t+\tau-1} \frac{1}{\tau} \operatorname{Cov}_{t}\left(m_{j+1}, R_{j+1}\right),
\end{aligned}
$$

where $m_{j+1}=\log M_{j+1}\left(=\log \beta\left[u^{\prime}\left(C_{j+1}\right) / u^{\prime}\left(C_{j}\right)\right]\left(Q_{j} / Q_{j+1}\right)\right)$ is the log pricing kernel, and $R_{j+1}$ is the one-period excess return of corporate bonds over Treasury bonds. Assuming that $v^{\prime \prime}(\cdot)<0, S_{t, \tau}$ is declining in $\left(\theta_{t}^{T}+\right.$ $\left.k^{P} \theta_{t}^{P}\right) / \mathrm{GDP}_{t}$. As long as $\theta_{j}^{A} / \mathrm{GDP}_{t}$ increases with $\theta_{j}^{T} / \mathrm{GDP}_{t}$, increases in Treasury supply lower the spread, $S_{t, \tau}$.

The derivation of this spread expression is in Appendix A. The derivation assumes that all relevant variables, including $m_{t}$ and changes in the corporate and Treasury bond yields, are normally distributed.

The spread reflects three terms: (1) the expected average Treasury convenience benefit over the next $\tau$ periods, (2) the expected average amount of default, and (3) a risk premium that depends on the covariance between the pricing kernel and the excess return on corporate over Treasury bonds.

Let us compare the short-term and long-term spread expressions. Note that shocks to both $\theta_{t}^{A} / \mathrm{GDP}_{t}$ and $\xi_{t}$ have an impact on the shortterm spread. The impact of these shocks on the long-term spread depends on the persistence of the shocks. In the data, a flight to quality (liquidity and safety) shock $\left(\xi_{t}\right)$ is likely to be short lived and should primarily affect short-term spreads. The debt-to-GDP ratio is quite persistent so that shocks to $\theta_{t}^{A} / \mathrm{GDP}_{t}$ will have a significant impact on both short- and long-term spreads. This logic tells us that the convenience yield as embodied in the long-term spread is primarily driven by $\theta_{t}^{A} / \mathrm{GDP}_{t}$, whereas variability in the short-term spread will partly be driven by $\xi_{t}{ }^{4}$ This is an advantage of using the long-term spread and data on $\theta_{t}^{A} / \mathrm{GDP}_{t}$ to estimate convenience yields. On the other hand, the corporate bonds we use to construct the short-term spread are closer to

\footnotetext{
${ }^{4}$ Here is a simple case to formalize these points. Suppose that the convenience yield function is

$$
v^{\prime}\left(\theta_{t}^{A} / \mathrm{GDP}_{t} ; \xi_{t}\right)=b_{0}+b_{1} \log \left(\theta_{t}^{A} / \mathrm{GDP}_{t}\right)+\log \xi_{t}
$$

Here, we have written the demand shock, $\xi_{t}$, to enter additively in the convenience yield and assumed a log convenience yield function, as we do in most of our empirical tests. The short-term spread equally reflects a supply term $b_{1} \log \left(\theta_{t}^{A} / \mathrm{GDP}_{t}\right)$ and a demand term $\log \xi_{t}$. Suppose that $\log \left(\theta_{t}^{A} / \mathrm{GDP}_{t}\right)$ is $\operatorname{AR}(1)$ with coefficient $\rho$ and that $\log \xi_{t}$ is independent and identically distributed (i.i.d.) with mean zero. Then it is easy to verify that the convenience yield component of the long-term spread is

$$
\sum_{j=t}^{t+\tau-1} \frac{1}{\tau} E_{t}\left[v^{\prime}\left(\theta_{j}^{A} / \mathrm{GDP}_{j} ; \xi_{j}\right)\right]=b_{0}+b_{1} \log \left(\theta_{t}^{A} / \mathrm{GDP}_{t}\right)\left(1+\rho+\rho^{2}+\cdots+\rho^{\tau-1}\right) \frac{1}{\tau}+\frac{\log \xi_{t}}{\tau} .
$$

If we take $\tau=20$ years (the maturity for the long spread in our study) and $\rho=0.95$ (consistent with data on the debt-to-GDP ratio), then the supply coefficient $(1+\rho+$ $\left.\rho^{2}+\cdots+\rho^{\tau-1}\right)(1 / \tau)$ is 0.64 and the demand coefficient $1 / \tau$ is 0.05 .
} 
default free. The corporate bonds used in the long-term spread carry greater default risk. Thus, the results based on the long-term spread are more sensitive to precise controls for default risk.

\section{B. Liquidity and Safety Attributes}

We now reintroduce the different liquidity and safety attributes of Treasuries and consider how one can test if these attributes are priced. Following equations (5) and (6), long- and short-term assets should be expected to have different convenience yields. To be precise, let us reconsider the short- and long-term spread expression. The short-term spread reflects liquidity and short-term safety:

$$
\begin{aligned}
S_{t, 1}= & v_{\text {liq }}^{\prime}\left(\frac{\theta_{t}^{T}+k^{\text {liq }} \theta_{t}^{P \text {,iq }}}{\mathrm{GDP}_{t}} ; \xi_{t}^{\text {liq }}\right) \\
& +v_{\text {short-safe }}^{\prime}\left(\frac{\theta_{t}^{T \text {,short }}+k^{\text {short-safe }} \theta_{t}^{P \text {,short-safe }}}{\operatorname{GDP}_{t}} ; \xi_{t}^{\text {short-safe }}\right) \\
& +\lambda_{t} E_{t}\left[L_{t+1}\right]+\operatorname{Cov}_{t}\left[M_{t+1}, \tilde{L}_{t+1}\right] / E_{t}\left[M_{t+1}\right] .
\end{aligned}
$$

The long-term spread (the spread for large $\tau$ ) reflects the expected liquidity and long-term safety attributes over the term of the bond:

$$
\begin{aligned}
S_{t, \tau}= & \sum_{j=t}^{t+\tau-1} \frac{1}{\tau} E_{t}\left[v_{\text {liq }}^{\prime}\left(\frac{\theta_{j}^{T}+k^{\text {liq }} \theta_{j}^{P \text {,liq }}}{\mathrm{GDP}_{j}} ; \xi_{j}^{\text {,liq }}\right)\right. \\
& \left.+v_{\text {long-safe }}^{\prime}\left(\frac{\theta_{j}^{T, \text { long }}+k^{\text {long-safe }} \theta_{j}^{P, \text { long-safe }}}{\mathrm{GDP}_{j}} ; \xi_{j}^{\text {long-safe }}\right)\right] \\
& +\sum_{j=t}^{t+\tau-1} \frac{1}{\tau} E_{t}\left[\lambda_{j} D_{j}\right]-\sum_{j=t}^{t+\tau-1} \frac{1}{\tau} \operatorname{Cov}_{t}\left(m_{j+1}, R_{j+1}\right) .
\end{aligned}
$$

We consider pairs of assets that have either similar liquidity and different safety or similar safety and different liquidity. The yield spread between these assets reflects only the price of liquidity or the price of safety. We can then test whether the price of the attribute captured by the yield spread changes with the relevant supply of Treasuries.

Consider first the spread between P2- and P1-rated commercial paper. The former has a higher default risk than the latter. The assets are shortterm but similarly illiquid as we document in the next section. Thus the P2-P1 spread purely reflects the value of short-term safety convenience.

PREDiction 3 (Impact of Treasury supply on the price of short-term safety). Consider that P2- and P1-rated commercial paper are equally liquid (i.e., $k_{P 2}^{\text {liq }}=k_{P 1}^{\text {liq }}$ ) but that $k_{P 1}^{\text {short-safe }}>k_{P 2}^{\text {short-safe }}$. Then, the spread between these bond yields is related to the stock of short-term Treasuries 
as follows:

$$
\begin{aligned}
S_{t, 1}^{P 2-P 1}= & \left(k_{P 1}^{\text {short-safe }}-k_{P 2}^{\text {short-safe }}\right) \\
& \times v_{\text {short-safe }}^{\prime}\left(\frac{\theta_{t}^{T \text {,short }}+k^{\text {short-safe }} \theta_{t}^{P \text {,short-safe }}}{\operatorname{GDP}_{t}} ; \xi_{t}^{\text {short-safe }}\right) \\
& +\lambda_{t, P 2} E_{t}\left[L_{t+1, P 2}\right]-\lambda_{t, P 1} E_{t}\left[L_{t+1, P 1}\right] \\
& +\operatorname{Cov}_{t}\left[M_{t+1}, \tilde{L}_{t+1, P 2}-\tilde{L}_{t+1, P 1}\right] / E_{t}\left[M_{t+1}\right] .
\end{aligned}
$$

If short-term safety is a priced attribute and Treasuries have this attribute, then increases in the supply of short-term Treasuries will lower $S_{t, 1}^{P 2-P 1}$ (as long as $\left[\theta_{t}^{T \text {,short }}+k^{\text {short-safe }} \theta_{t}^{P \text {,short-safe }}\right] / \mathrm{GDP}_{t}$ increases in $\theta_{t}^{T \text {,short }} / \mathrm{GDP}_{t}$ ).

In terms of the estimation, the P2-P1 spread is directly a function of the supply of short-term convenience assets. There is extensive evidence that both the private sector and the Treasury actively manage the maturity structure of debt. To get around any endogeneity issues stemming from this behavior, we use instrumental variables (IV) regressions, using $\theta_{t}^{T} / \mathrm{GDP}_{t}$ as an instrument for $\theta_{t}^{T \text {,short }} / \mathrm{GDP}_{t}$ (a similar comment applies for testing prediction 4 below).

Next consider a similar prediction but based on the spread between two long-term corporate bonds.

Prediction 4 (Impact of Treasury supply on the price of long-term safety). Take two long-term corporate bonds, an Aaa-rated bond and a Baa-rated bond. Consider that these bonds are equally liquid (i.e., $\left.k_{\text {Aaa }}^{\text {liq }}=k_{\text {Baa }}^{\text {liq }}\right)$ but that $k_{\text {Aaa }}^{\text {long-safe }}>k_{\text {Baa }}^{\text {long-safe }}$. Then, the spread between these bond yields is related to the stock of long-term Treasuries as follows:

$$
\begin{aligned}
S_{t, \tau}^{\text {Baa-Aaa }}= & \left(k_{\text {Aaa }}^{\text {long-safe }}-k_{\text {Baa }}^{\text {long-safe }}\right) \\
& \times \sum_{j=t}^{t+\tau-1} \frac{1}{\tau} E_{t}\left[v_{\text {long-safe }}^{\prime}\left(\frac{\theta_{j}^{T \text { long }}+k^{\text {long-safe }} \theta_{j}^{\text {Plong-safe }}}{\mathrm{GDP}_{j}} ; \xi_{j}^{\text {long-safe }}\right)\right] \\
& +\sum_{j=t}^{t+\tau-1} E_{t}\left[\lambda_{j}^{\text {Baa }} D_{j}^{\text {Baa }}-\lambda_{j}^{\text {Aaa }} D_{j}^{\text {Aaa }}\right] \\
& -\sum_{j=t}^{t+\tau-1} \frac{1}{\tau} \operatorname{Cov}_{t}\left(m_{j+1}, R_{j+1}^{\text {Baa-Aaa }}\right) .
\end{aligned}
$$

If long-term safety is a priced attribute and Treasuries have this attribute, then increases in the supply of long-term Treasuries will lower $S_{t, \tau}^{\text {Baa-Aaa }}$ (as long as $\left[\theta_{t}^{T \text { long }}+k^{\text {long-safe }} \theta_{t}^{P \text {,long-safe }}\right] / \mathrm{GDP}_{t}$ increases in $\theta_{t}^{T \text { long }} / \mathrm{GDP}_{t}$ ).

A similar comparison, but now getting at the liquidity attribute, is made through the following prediction.

Prediction 5 (Impact of Treasury supply on the price of liquidity). Consider a one-period Treasury bond that offers one unit of li- 
quidity and is default free. Consider also a Federal Deposit Insurance Corporation (FDIC) insured bank deposit that is default free but offers only $k^{\text {liq }}<1$ units of liquidity. Then, the one-period spread between these bonds is related to the stock of Treasuries as follows:

$$
S_{t, 1}^{\mathrm{FDIC}}=i_{t}^{\mathrm{FDIC}}-i_{t}^{T}=\left(1-k^{\mathrm{liq}}\right) v_{\mathrm{liq}}^{\prime}\left(\frac{\theta_{t}^{T}+k^{\mathrm{liq}} \theta_{t}^{P, \mathrm{liq}}}{\mathrm{GDP}_{t}} ; \xi_{t}^{\mathrm{liq}}\right) .
$$

If liquidity is a priced attribute and Treasuries have this attribute, then increases in the supply of Treasuries will lower $S_{t, 1}^{\mathrm{FDIC}}$ (as long as $\left[\theta_{t}^{T}+\right.$ $\left.k^{\mathrm{liq}} \theta_{t}^{P, \mathrm{liq}}\right] / \mathrm{GDP}_{t}$ increases in $\left.\theta_{t}^{T} / \mathrm{GDP}_{t}\right)$.

\section{Evidence}

Details on the data construction for each table as well as the sources for all variables used in our regressions are in Appendix B. The regressions all use data at an annual frequency and for as long a period as is feasible given the variables included in the regression.

\section{A. Impact of Treasury Supply on Spreads}

Predictions 1 and 2 state that under the convenience yield hypothesis, increases in Treasury supply should reduce short spreads and long spreads. Table 1 presents regressions confirming these predictions.

The key explanatory variable in the regressions reported in the tables is the log of debt/GDP, where debt/GDP is the market value of the outstanding stock of US Treasuries divided by US GDP. The measure of government debt corresponds to what is referred to as publicly held debt. It includes debt held by the Federal Reserve but excludes debt held by other parts of the government such as the Social Security Trust Fund. Our results do not change appreciably if we exclude the holdings of the Federal Reserve. The debt measure is as of the end of the government's fiscal year, that is, the end of June up to and including 1976 and the end of September from 1977 on. Statistics on government debt are typically reported in face value terms, whereas we are interested in the market value of debt. ${ }^{5}$ Appendix B details how we adjust face values to come up with the market value of debt.

The theoretical measure of convenience yield (convenience benefit) is $v^{\prime}\left(\theta_{t}^{A} / \mathrm{GDP}_{t}\right)$, where $\theta_{t}^{A}$ includes both Treasury debt and private-sector convenience assets. Predictions 1 and 2 are that the convenience yield is declining in $\theta_{t}^{A} / \mathrm{GDP}_{t}$. As we have noted, as long as private-sector convenience asset supplies do not change more than one for one (in

\footnotetext{
${ }^{5}$ Doepke and Schneider (2006) encounter the same issue in studying how inflation affects the market value of debt. They offer a procedure to compute market values of debt.
} 





the opposite direction) in response to changes in Treasury debt, we can verify predictions 1 and 2 by examining the impact of changes in Treasury debt on price measures. The regression coefficient on Treasury debt should be interpreted as reflecting the effect, net of the privatesector supply response, of a change in Treasury debt on the Treasury convenience yield.

\section{Long-Term Spreads}

In table 1 , the Treasury debt variable is the logarithm of the debt-toGDP ratio, and the dependent variable in each regression is a bond yield spread measured in percentage terms. Panels A and B present results for long-term spreads, namely, the spread between long-term Aaarated corporate bonds and long-term Treasuries (panel A) and the spread between long-term Baa-rated corporate bonds and long-term Treasuries (panel B). We use the log functional form because it provides a good fit and requires estimation of only one parameter. A drawback with the $\log$ function is that it does not asymptote to zero as debt-toGDP rises. We estimate an alternative functional form with the asymptote property in Section III.C.

The regressions in table 1 are estimated using ordinary least squares (OLS). We report $t$-statistics adjusting the standard errors assuming an $\mathrm{AR}(1)$ error structure. The AR(1) structure is motivated by a standard Box-Jenkins analysis of the autocorrelation function and partial autocorrelation function of the error terms. The first-order autocorrelations are included in the table. Serial correlation is pronounced only in the long-term spread regressions of panel A. For consistency across columns, we use the $\mathrm{AR}(1)$ adjustment in all columns though it makes little difference except in panel A, where $t$-statistics based on "standard" OLS standard errors (assuming an i.i.d. error term) would be substantially larger than those presented. An alternative to OLS estimation with an $\mathrm{AR}(1)$ standard error adjustment would be to use generalized least squares (GLS) estimation. However, we suspect that $\log (\mathrm{debt} / \mathrm{GDP})$ is not a perfect measure of the convenience state variable in the longterm spread regressions, $\sum_{j=t}^{t+\tau-1}(1 / \tau) E_{t}\left[v^{\prime}\left(\theta_{j}^{A} / \mathrm{GDP}_{j} ; \xi_{j}\right)\right]$. It is likely that the private-sector expectations of this sum involve variables other than the current debt-to-GDP ratio (notably information about the likely development of the government budget). If so, then debt-to-GDP is measured with error implying downward bias in the impact of Treasury supply on spreads (under standard assumptions about the measurement error). GLS estimation would be more affected by the measurement error issue. To see this, suppose that the error autocorrelation was close to one. Then GLS would effectively transform the data to run a first-difference regression. While in levels the variance of $\log (\mathrm{debt} / \mathrm{GDP})$ is likely to 
be large relative to that of the measurement error, in first differences this will not be the case since the high persistence of $\log (\mathrm{debt} / \mathrm{GDP})$ means that the volatility of its first difference is low (a formal Monte Carlo study of this issue is available on request). These considerations lead us to present OLS regressions with standard errors adjusted for the serial correlation. We emphasize that our OLS regression coefficients are likely to be conservative, understating the impact of Treasury supply on convenience yields. ${ }^{6}$

The coefficient of -0.746 in column 1 of table 1 implies that a decrease of one standard deviation in debt-to-GDP from its mean value of 0.439 to 0.243 increases the convenience yield component of the AaaTreasury spread by as much as 0.44 percent ( 44 basis points).

Default risk is an important component of the bond spreads. In columns 2 and 3 we show that the impact of Treasury supply on the AaaTreasury spread is robust to including default controls. Moody's Investors Service (2005) estimates, on the basis of data from 1920-2004, that the default rate on Aaa-rated bonds over a 10-year period is around 1 percent, whereas for Baa bonds this default rate is 8 percent. In column 2, we control for default risk using a default measure computed by Moody's Analytics, which is the current industry standard in calculating default probabilities for corporate bond pricing. Its computation is based on Merton (1974), which treats the debt of a firm as a riskless asset minus a put option on the firm's assets. Using capital structure information and Merton's option decomposition of capital structure, Moody's infers the firm's asset value and asset value volatility. This information allows it to compute the distance to default on debt (i.e., moneyness of the put option). Using historical default information in a nonlinear regression, Moody's estimates how distance-to-default translates into default probabilities. We use the median expected default frequency (EDF) credit measure reported by Moody's Analytics for large firms (defined as firms with book value of assets $>\$ 300$ million in inflation-adjusted dollars). The EDF credit measure is available from 1969 to 2008. The results in column 2 show that the EDF credit measure is informative. Crucially, the coefficient on $\log (\mathrm{debt} / \mathrm{GDP})$ remains highly significant and of roughly the same magnitude as in other spe-

\footnotetext{
${ }^{6}$ A standard solution to the bias problem would be an IV approach. If the error term was serially uncorrelated, one could use lagged values of $\log (\mathrm{debt} / \mathrm{GDP})$ as the instrument for $\log (\mathrm{debt} / \mathrm{GDP})$. With serially correlated errors one should lag the instrument far enough to avoid correlation between the instrument and the error term. We find that the coefficient on $\log (\mathrm{debt} / \mathrm{GDP})$ is larger in IV estimations and keeps increasing as the instrument is lagged further. This suggests that the measurement error concern is relevant but that it is unclear how far to lag the instrument and therefore more conservative to report only OLS results.
} 
cifications. $^{7}$ The EDF measure is available only back to 1969 , whereas we would like a default measure that goes back to 1926. Because the EDF measure is option pricing based, the key input into the measure is stock return volatility. Thus for the longer sample we use stock return volatility. We measure the weekly returns on the value-weighted Standard \& Poors index based on daily returns. As the volatility measure for a given year, we compute the standard deviation of the weekly log returns over the year leading up to the end of the government fiscal year (the date of the debt-to-GDP observation). We annualize this standard deviation by multiplying by the square root of 52 . Over the 40 years for which we have both EDF data and stock market volatility estimates, the correlation of these two default measures is .76. This provides strong support for the use of stock market volatility as a default control over the full sample. Column 3 presents results using the stock return volatility measure. Volatility is significantly related to the spread, but the coefficient on $\log (\mathrm{debt} / \mathrm{GDP})$ is roughly the same as in previous specifications. Furthermore, the economic effects of changes in the default risk measures on the Aaa-Treasury spread are modest compared to the effect of Treasury supply. A one-standard-deviation increase in the EDF increases the Aaa-Treasury spread by 23 basis points whereas a onestandard-deviation increase in stock return volatility increases it by 10 basis points.

The regressions in columns 2 and 3 include the slope of the yield curve as a further control. We measure the slope as the spread between the 10-year Treasury yield and the 3-month Treasury yield (slope). The slope of the yield curve is a measure of the state of the business cycle. It is known to predict the excess returns on stocks and may also pick up time-varying risk premia on corporate bonds. For example, if investors are more risk averse in a recession, when the slope is high, they will demand a higher risk premium to hold corporate bonds. Thus, the slope of the yield curve serves as a measure of variation in the risk premium component of the bond spread, that is, the term involving $\operatorname{Cov}_{t}(\cdot)$ in prediction 2. We also note that to the extent that corporate default risk is likely to vary with the business cycle, the slope variable

${ }^{7}$ Another issue that arises in interpreting the long-term spread regressions is callability. Duffee (1998) points out that the Moody's Aaa index includes callable corporate bonds. Thus, the Aaa-Treasury spread may also reflect an interest rate option. Duffee proxies for the moneyness of the call option using the level of interest rates and shows that yield spreads vary significantly with the level of interest rates. Following this approach, we have investigated adding levels of short- and long-term Treasury yields as explanatory variables in our long-term spread regressions and have found that it has no appreciable effects on the coefficient on $\log (\mathrm{debt} / \mathrm{GDP})$. A further issue that affects spreads between corporate bonds and Treasuries is that Treasuries are exempt from state taxes but corporate bonds typically are not. We have run regressions that include a control for the state tax effect on the spread (the product of the average state tax rate and the Aaa yield) and find that our results are largely unchanged. 
can furthermore help control for the expected default in the yield spread.

For the results for the Baa-Treasury spread in panel $\mathrm{B}$, the coefficient on $\log (\mathrm{debt} / \mathrm{GDP})$ in column 5 is considerably higher than the coefficient in column 3 for the Aaa-Treasury spread and implies that a decrease of one standard deviation in debt-to-GDP from its mean value of 0.439 to 0.243 increases the convenience yield component of the BaaTreasury spread by 0.77 percent ( 77 basis points). The difference in results between panels $A$ and $B$ suggests that Aaa bonds offer some convenience services of Treasuries and thus that the Baa-Treasury spread is more appropriate for capturing the full effect of Treasury supply on the Treasury convenience yield. We present further evidence for this interpretation in table 2 below.

\section{Short-Term Spreads}

Panels C and D of table 1 are based on short-term bond spreads, with panel $\mathrm{C}$ showing results for the spread between the highest-rated commercial paper (CP) and Treasury bills, both of 3-month maturity, and panel D focusing on the spread between lower-grade commercial paper (A2/P2-rated paper) and Treasury bills. The shorter time period is used in column 9 because yields for lower-grade commercial paper are available only starting in $1974 .^{8}$

Short- and long-term spreads may contain different convenience attributes, so we should not expect the coefficients on $\log (\mathrm{debt} / \mathrm{GDP})$ to be the same across the different maturities. Nonetheless, the regressions for short-term spreads show that the effects of changes in Treasury supply on short-term spreads have magnitudes fairly similar to that of the effect on long-term spreads. Consistent with the results for long-term spreads, the higher coefficient in panel $\mathrm{D}$ than in panel $\mathrm{C}$ is also indicative that the high-grade commercial paper in panel $\mathrm{C}$ (like the Aaa-rated longterm bonds in panel A) has some convenience attributes.

It is important to note that our evidence on the spread between commercial paper and Treasury bills is less likely to be affected by issues of omitted expected default or default risk premium controls than the evidence on the Aaa-Treasury spread. This is the case because historical default rates on the highest-rated commercial paper $(\mathrm{A} 1 / \mathrm{P} 1)$ are very low, with literally zero defaults during the period 1972-2000 for which Moody's Investors Service (2000) provides data on commercial paper

\footnotetext{
${ }^{8}$ When analyzing lower-grade commercial paper yields, we drop 2008. This year is a dramatic outlier in terms of the lower-grade commercial paper yield, likely because of increased default risk. Since our EDF default control, which pertains to corporate bonds, may not be as good a control for default risk for commercial paper as for corporate bonds, we drop 2008 in our analysis of lower-grade commercial paper.
} 
defaults. This latter observation can also explain why the default controls are statistically not different from zero in the commercial paper regressions in columns 7 and 9. Over a 3-month period, a highly rated firm may run into financial difficulties and be downgraded but is unlikely to enter bankruptcy.

\section{B. Evidence for the Existence of Priced Liquidity and Safety Attributes}

We next test predictions 3-5 that the convenience yield on Treasuries is a reflection of two priced attributes: liquidity and safety. We consider pairs of assets with different liquidity but similar safety or with different safety but similar liquidity. Table 2 presents the results.

Columns 1 and 2 of table 2 present evidence for the existence of a unique demand for long-term safe assets leading to a positive convenience price of the long-term safety attribute. The dependent variable is the spread between Baa and Aaa corporate bonds. Baa bonds carry more default risk than Aaa bonds but are similarly illiquid. Chen, Lesmond, and Wei (2007) study corporate bond liquidity in a large sample of corporate bonds over the period 1995-2003 and report that the spread between bid and ask prices (as a percentage of the price) on Aaa corporate bonds averaged 52 basis points whereas it averaged 59 basis points on the Baa corporate bonds. These spreads compare to about 10-20 basis points for Treasury bonds (calculated on the basis of typical dollar spreads of two to three 32 nds per $\$ 100$ face value according to Longstaff [2004]). Thus any convenience yield as measured in the Baa-Aaa spread can reflect only the price of the long-term safety attribute as opposed to a liquidity effect. Column 1 shows that an increase in Treasury supply leads to a decrease in the Baa-Aaa spread, confirming the existence of a priced long-term safety attribute driven by Treasury supply. Theory suggests that the supply of long-term safe assets rather than the total supply of Treasuries should drive the price of long-term safety. In column 2, we present results using the supply of long-term Treasury debt, measured as the supply of Treasuries with greater than 10 years' remaining maturity divided by GDP. Since the maturity structure of government debt is likely to be endogenous, we instrument the long-term supply by powers of debt/GDP. The first stage of the IV regression is not reported for brevity but shows a highly significant relation between total debt and the measure of long-term debt. The coefficient of -0.304 means that a one-standard-deviation decrease in the supply of long-term Treasuries (as a ratio to GDP) from its mean value of 0.079 to 0.021 raises the price of long-term safety by 40 basis points.

Columns 3 and 4 present evidence for the existence of a priced shortterm safety attribute driven by Treasury supply. The dependent variable is the spread between 3-month A2/P2-rated and A1/P1-rated commer- 
TABLE 2

Impact of Treasury Supply on the Price of Safety and the Price of Liquidity

\begin{tabular}{|c|c|c|c|c|c|c|}
\hline & \multicolumn{4}{|c|}{ A. Price of Safety } & \multicolumn{2}{|c|}{ B. Price of Liquidity } \\
\hline & \multicolumn{2}{|c|}{$S^{\text {Baa-Aaa }}$} & \multicolumn{2}{|c|}{$S^{\mathrm{P2}-\mathrm{Pl}}$} & \multirow{2}{*}{$\begin{array}{c}S^{\text {FDICinsuredCDs-Bills }} \\
1984-2008 \\
(5)\end{array}$} & \multirow{2}{*}{$\begin{array}{c}S^{\text {Time/SavingsAccounts-Bill }} \\
1935-65 \\
(6)\end{array}$} \\
\hline & $\begin{array}{c}1926- \\
2008 \\
(1)\end{array}$ & $\begin{array}{l}1926- \\
2008 \\
(2)\end{array}$ & $\begin{array}{l}1974- \\
2007 \\
(3)\end{array}$ & $\begin{array}{c}1974- \\
2007 \\
(4)\end{array}$ & & \\
\hline $\begin{array}{c}\log (\text { debt } / \\
\text { GDP })\end{array}$ & $\begin{array}{r}-.510 \\
{[-3.45]}\end{array}$ & & $\begin{array}{r}-.888 \\
{[-4.34]}\end{array}$ & & $\begin{array}{c}-1.884 \\
{[-1.71]}\end{array}$ & $\begin{array}{r}-.690 \\
{[-2.57]}\end{array}$ \\
\hline $\begin{array}{c}\log (\text { debt }>10- \\
\text { year matur- } \\
\text { ity/GDP })^{*}\end{array}$ & & $\begin{array}{r}-.304 \\
{[-2.44]}\end{array}$ & & & & \\
\hline $\begin{array}{c}\log (\text { debt } \leq 1- \\
\text { year matur- } \\
\text { ity } / \text { GDP })^{*}\end{array}$ & & & & $\begin{array}{r}-1.462 \\
{[-2.84]}\end{array}$ & & \\
\hline Volatility & $\begin{array}{r}5.031 \\
{[6.47]}\end{array}$ & $\begin{array}{r}6.232 \\
{[6.65]}\end{array}$ & & & & \\
\hline EDF & & & $\begin{array}{c}.074 \\
{[.35]}\end{array}$ & $\begin{array}{r}.019 \\
{[.07]}\end{array}$ & & \\
\hline Slope & $\begin{array}{r}.232 \\
{[4.20]}\end{array}$ & $\begin{array}{r}.211 \\
{[3.29]}\end{array}$ & $\begin{array}{c}.014 \\
{[.42]}\end{array}$ & $\begin{array}{r}.055 \\
{[1.13]}\end{array}$ & $\begin{array}{r}.101 \\
{[.88]}\end{array}$ & $\begin{array}{r}1.181 \\
{[10.04]}\end{array}$ \\
\hline Constant & $\begin{array}{r}.660 \\
{[4.54]}\end{array}$ & $\begin{array}{r}.264 \\
{[.74]}\end{array}$ & $\begin{array}{r}-.508 \\
{[-2.39]}\end{array}$ & $\begin{array}{r}-2.679 \\
{[-2.47]}\end{array}$ & $\begin{array}{r}-1.486 \\
{[-1.52]}\end{array}$ & $\begin{array}{r}-.170 \\
{[-.95]}\end{array}$ \\
\hline $\begin{array}{l}\text { Observations } \\
R^{2}\end{array}$ & $\begin{array}{l}83 \\
.600\end{array}$ & 83 & $\begin{array}{l}34 \\
.497\end{array}$ & 34 & $\begin{array}{l}25 \\
.233\end{array}$ & $\begin{array}{l}31 \\
.898\end{array}$ \\
\hline $\begin{array}{l}\text { Estimation } \\
\text { method } \\
\text { Error term }\end{array}$ & $\begin{array}{c}\text { OLS } \\
\operatorname{AR}(1)\end{array}$ & $\begin{array}{c}\mathrm{IV} \\
\mathrm{AR}(1)\end{array}$ & $\begin{array}{c}\text { OLS } \\
\operatorname{AR}(1)\end{array}$ & $\begin{array}{c}\mathrm{IV} \\
\mathrm{AR}(1)\end{array}$ & $\begin{array}{c}\text { OLS } \\
\operatorname{AR}(1)\end{array}$ & $\begin{array}{c}\text { OLS } \\
\operatorname{AR}(1)\end{array}$ \\
\hline
\end{tabular}

Note.-The dependent variables are the spread between Baa-rated corporate bonds and Aaa-rated bonds (cols. 1 and 2), the spread between A2/P2-rated and A1/P1-rated commercial paper (cols. 3 and 4 ), the spread between the interest rate on FDIC-insured 6-month CDs and 6-month Treasury bills (col. 5), and the spread between the average interest rate paid by banks on time and savings deposits and 6-month Treasury bills (col. 6 ). Independent variables are the $\log$ of the ratio of the market value of Treasury debt outstanding to US GDP, the $\log$ of the ratio of the market value of Treasury debt with remaining maturity greater than 10 years to US GDP, the log of the ratio of the market value of Treasury debt with remaining maturity less than 1 year to US GDP, the annualized standard deviation of weekly $\log$ stock returns on the S\&P 500 index (volatility), the expected default frequency for corporate bonds (EDF), and the slope of the Treasury yield curve measured as the spread between the 10-year Treasury yield and the 3-month Treasury yield in cols. 1-4 and as the spread between the 10-year Treasury yield and the 6-month Treasury yield in cols. 5 and 6. Appendix B provides the precise definitions of all variables. EDF, volatility, and slope controls are demeaned. Regressions are estimated by OLS or instrumental variables (two-stage least squares), where we use instruments debt/ GDP, $(\mathrm{debt} / \mathrm{GDP})^{2}$, and (debt/GDP) ${ }^{3}$, as indicated. The standard errors are adjusted assuming that errors are $\mathrm{AR}(1)$. We use the Box-Jenkins methodology for identifying the error structure. $t$-statistics are in brackets.

* Instrumented by (debt/GDP), (debt/GDP) ${ }^{2}$, and (debt/GDP) ${ }^{3}$. 
cial paper. Over a 3-month period, on the basis of data from 1972 to 2000, Moody's Investors Service (2000) estimates that the default probability on $\mathrm{A} 2 / \mathrm{P} 2$ paper is 0.02 percent and is 0 percent for $\mathrm{A} 1 / \mathrm{P} 1$ paper. Thus there is a (small) difference in the safety of these short-term assets. As for liquidity, there is little secondary market trading activity in commercial paper of any rating. On the basis of data from 1998 to 2003, Covitz and Downing (2007) report that most of the commercial paper activity is in terms of new issuance. Secondary market transactions account for only about 8 percent of daily market trading activity by face value. Using trading volume as a proxy for liquidity and EDF, and credit rating and stock volatility as proxies for credit risk, Covitz and Downing find that, in the cross section of commercial paper, liquidity differences explain very little of the variation in rates. Thus, any convenience yield as measured in the P2-P1 spread reflects the price of the short-term safety attribute. In column 3 we use total Treasury supply, and column 4 presents an IV regression, where the supply measure is of Treasuries with maturity less than 1 year divided by GDP. The results in both columns 3 and 4 confirm the existence of a significant price of shortterm safety. The coefficient of -1.462 in column 4 means that a onestandard-deviation decrease in the supply of short-term Treasuries (as a ratio to GDP) from its mean value of 0.124 to 0.104 raises the price of short-term safety by 26 basis points.

Columns 5 and 6 present evidence for the existence of a priced liquidity attribute of Treasuries, comparing assets with similar safety but different liquidity. The dependent variable in column 5 is the spread between the interest rate customers receive on 6-month FDIC-insured certificates of deposit (CDs) and 6-month Treasury bills. We start the CD series in 1984, corresponding to the phasing out of Regulation $Q$ (see Gilbert 1986). Given FDIC insurance, any convenience yield documented via Treasury supply affecting this spread can reflect only a liquidity attribute. The supply variable in the regression is the total supply of Treasuries since all Treasuries carry the liquidity attribute. The impact of Treasury supply on the CD-Treasury spread confirms the existence of a significant price of liquidity over the 1984-2008 period. To obtain evidence going back further, column 6 uses data on the spread between the average interest rate paid on time and savings deposits and Treasury bill rates. Since interest rate ceilings set by Regulation $Q$ were binding at various points during the period from 1966 until their phaseout in the mid-1980s (see again Gilbert 1986), we focus on data from 1934 - the first year of FDIC insurance-to 1965 (we do not have CD rate data from this earlier period). The interest rate on time and savings deposits is less ideal than the CD rate because FDIC insurance does not apply to large deposits, so the interest rate on time and savings deposits reflects a mix of insured accounts and noninsured accounts. The FDIC 
reports that insurance applied to approximately half of all deposits at commercial banks over the period 1934-65 (FDIC 1984). As a result, there is a slight difference in the safety of the average time and savings deposit and of Treasuries. ${ }^{9}$ In addition, the time and savings deposits are an amalgam of deposits with different maturities, making it more difficult to maturity match the series to Treasuries. We match it to 6month Treasuries and include a slope control to deal with the maturity mismatch. Subject to these qualifiers, the evidence in column 6 of an impact of Treasury supply on the interest rate spread between time and savings deposits and Treasuries provides further support that investors value liquidity with Treasury supply driving the price of liquidity. ${ }^{10}$

We can gauge the magnitude of the liquidity effect in two different ways. First, note that the deposits in column 6 include very short-term savings accounts that are quite liquid. That is, the spread in column 6 reflects the difference between a very liquid Treasury and a liquid bank account, so that the spread reflects an underestimate of how much Treasury yields are reduced by the liquidity attribute of Treasuries. The spread in column 5 is a more pure read on the liquidity impact on Treasury yields, although the sample is quite short. The coefficient of -1.884 means that a one-standard-deviation decrease in the supply of Treasuries (as a ratio to GDP) from its mean value of 0.439 to 0.243 raises the price of liquidity by 111 basis points. A second estimate of the impact of Treasury supply on the price of liquidity comes from the regression in table 1, column 7, which is the high-grade CP spread regression for 1969-2008. Considering the spread between CP and Treasury bills also deals with concerns that the spread between insured CD rates and Treasury bills partly reflects intermediation costs or retail deposit effects. We have noted that data from 1972 on indicate that there has never been a default on high-grade CP. The coefficient on the default controls in that regression is also small and statistically not different from zero. Using this spread as a measure of liquidity, we find that a one-standard-deviation decrease in the supply of Treasuries (as a ratio to GDP) from its mean value of 0.439 to 0.243 raises the price of liquidity by 57 basis points.

\section{Quantifying the Convenience Yield}

We next turn to quantifying the level of the convenience yield. Results from the $\log$ specification pin down the derivative of the convenience

\footnotetext{
${ }^{9}$ Including the fraction of deposits that are insured as a control does not affect the results, and this variable is not a significant determinant of the spread.

${ }^{10}$ Note that we focus on time and savings account deposit rates. Checking deposits, and not time and savings deposits, are conventionally thought to provide a medium of exchange attribute.
} 
TABLE 3

Impact of Treasury Supply on Bond Spreads: Piecewise-Linear Specification

\begin{tabular}{lccccc}
\hline \hline & \multicolumn{2}{c}{ A. AaA-Treasury } & & \multicolumn{2}{c}{ B. BAa-Treasury } \\
\cline { 2 - 3 } \cline { 5 - 6 } & $1919-2008$ & $1926-2008$ & & $1919-2008$ & $1926-2008$ \\
& $(1)$ & $(2)$ & & $(3)$ & $(4)$ \\
\hline$b_{0}$ & .319 & .347 & & 1.019 & 1.200 \\
& {$[1.80]$} & {$[2.55]$} & & {$[1.94]$} & {$[7.68]$} \\
$b_{1}$ & 2.590 & 3.075 & & 4.309 & 4.952 \\
& {$[4.06]$} & {$[5.17]$} & & {$[2.64]$} & {$[6.76]$} \\
$b_{2}$ & .584 & .548 & & .626 & .546 \\
& {$[7.02]$} & {$[9.74]$} & & {$[4.22]$} & {$[12.92]$} \\
Volatility & & 1.206 & & 6.215 \\
& & {$[1.93]$} & & {$[6.98]$} \\
Slope & & .096 & & .334 \\
& .479 & {$[2.43]$} & & & {$[5.07]$} \\
$R^{2}$ & 90 & 8618 & .290 & .704 \\
Observations & & 83 & 90 & 83 \\
\hline
\end{tabular}

Note.-This table estimates a piecewise-linear specification for the relation between Treasury supply and bond spreads. The function estimated is $b_{0}+b_{1} \times \max \left[b_{2}-\right.$ debt/GDP, 0]. The dependent variables are long-term yield spreads between corporate and Treasury bonds, measured in percentage units. Independent variables are the ratio of the market value of Treasury debt outstanding to US GDP and controls for the default risk and default risk premium on corporate bonds. Volatility is the annualized standard deviation of weekly log stock returns on the S\&P 500 index. Slope is the slope of the Treasury yield curve measured as the spread between the 10-year Treasury yield and the 3-month Treasury yield. Appendix B provides the precise definitions of all variables. Volatility and slope are demeaned. Regressions are estimated by nonlinear least squares. The standard errors are adjusted assuming that errors are $\operatorname{AR}(1)$. We use the Box-Jenkins methodology for identifying the error structure. $t$-statistics are in brackets.

yield with respect to Treasury supply but do not pin down the level of the convenience yield as a function of Treasury supply. Theory suggests that the value of convenience should go to zero given sufficient convenience assets. Imposing this asymptote property allows us to quantify the level of the convenience yield, since the convenience yield at some $\theta_{t}^{T}$ given an estimated relation between spreads and Treasury supply of $f\left(\theta^{T} / \mathrm{GDP}\right)$ is simply $f\left(\theta_{t}^{T} / \mathrm{GDP}_{t}\right)-f(\infty)$ (i.e., the distance between the predicted spread and the estimated asymptote).

The log function does not have the asymptote property. Table 3 reports results in which we model the convenience yield with a function that is piecewise linear in Treasury supply, $b_{1} \max \left[b_{2}-\right.$ debt/GDP, 0]. Visually, the piecewise linear function appears to be a good fit of the relation as depicted in figure 1 . Indeed, the $R^{2}$ 's for the piecewise linear function rise a bit relative to the log function. Regressions are estimated by nonlinear least squares. As in table 1, the standard errors are adjusted assuming that the error term is $\operatorname{AR}(1)$.

The term $b_{1} \max \left[b_{2}-\right.$ debt/GDP, 0$]$ is the convenience yield on long- 
term Treasury debt as a function of the debt-to-GDP ratio. Consider the estimates from column 4 for the Baa-Treasury spread. We can evaluate the convenience yield function at historical values of the debt-to-GDP ratio from 1926 to 2008 and average these numbers to come up with the average value of the convenience yield over our sample. This computation gives 73 basis points. ${ }^{11}$ The Baa-Treasury spread reflects both long-term safety and liquidity. We have argued that the Baa-Aaa spread is driven only by long-term safety, whereas the Aaa-Treasury spread is primarily driven by liquidity given the low default rate on Aaa bonds. To provide a sense of the relative magnitudes of the safety and liquidity convenience components, we make the simplifying assumption that the Aaa-Treasury spread reflects only liquidity whereas the Baa-Aaa spread reflects only safety. On the basis of the Aaa-Treasury estimates of column 2 , the average liquidity convenience is 46 basis points. This number should be interpreted as an upper bound for liquidity convenience since the Aaa-Treasury spread does contain some safety convenience as well (since Aaa bonds are not quite as safe as Treasuries). Further, subtracting 46 from 73 gives us that safety convenience is worth 27 basis points on average (a lower bound since Aaa's do carry some default risk).

Are these estimates plausible on the basis of the existing literature? Consider liquidity first. Figure 1 in Krishnamurthy (2002) documents that the yield spread between the on-the-run liquid 30-year Treasury bond and the off-the-run less liquid 30-year Treasury bond was 12 basis points on February 9, 2001. In price terms, if the modified duration of the bonds is taken to be 12 years, the on-the-run bond was priced at

11 There is an important caveat in interpreting the piecewise-linear estimates. The estimates of $b_{0}$ (the intercept) and $b_{2}$ (the kink point) are heavily affected by observations in the right tail of fig. 1 (i.e., high debt-to-GDP ratios). These high ratios occur only during the $1940 \mathrm{~s}$ and $1950 \mathrm{~s}$, so the parameter estimates are influenced by the idiosyncrasies of the war period. In an effort to help finance the war debt at low interest rates, the Federal Reserve committed to purchasing long-term Treasury bonds at a floor below prevailing market prices, thereby inducing long-term Treasury rates to be lower than market forces would have otherwise dictated. As events played out, the Federal Reserve did not in fact accumulate many long-term Treasuries, but even so, the commitment to a floor should be expected to affect prices. As a result, our estimates of $b_{0}$ are biased upward-implying that our above estimate of an average Treasury convenience yield of 73 basis points is conservative-and estimates of $b_{2}$ are biased downward. The Federal Reserve intervened much more strongly in the Treasury bill market. Policy at the time effectively allowed commercial banks to carry Treasury bills as interest-bearing reserves because the Federal Reserve allowed banks to freely exchange Treasury bills for reserves at a fixed price. In addition, beginning in 1943, the Federal Reserve directly purchased a large share of newly issued Treasury bills, whereas long-term bonds were held by a variety of investors. The Federal Reserve directly held 72 percent of total Treasury bills outstanding in 1944. See Wicker (1969) for further details on all of these points. We present piecewise-linear regressions for the long-term spreads, subject to the caveat noted above, but we do not present results for the short-term spreads on grounds that they are likely largely uninformative about convenience yields. We also note, as can be seen from cols. 2, 4, 7, and 9 in table 1, that our main results about the impact of Treasury supply on yields hold for subsamples that do not include the war period. 
1.44 percent over the off-the-run bond. Krishnamurthy notes that this difference will converge to a price premium of 0.36 percentage points over the next 9 months. Thus, the annualized liquidity convenience yield on the on-the-run bond was 144 basis points $(=[1.44-0.36] \times$ $[12 / 9] \times 100) .{ }^{12}$ This computation demonstrates that liquidity premia on Treasury bonds are indeed quite large. Our estimate, which is roughly one-third of that from the on-the-run bond, likely arises from the fact that we measure a liquidity premium on all Treasuries and not only the exceptionally liquid on-the-run bond.

Consider long-term safety next. Longstaff et al. (2005) study the pricing of corporate bonds relative to Treasury bonds, using information from the credit default swap market to pin down the default component. ${ }^{13}$ As with most papers in the literature, their paper finds that there is a substantial nondefault component in the corporate bond spreads. Their estimates put the average nondefault component at 65 basis points, which is in line with our overall convenience yield estimates. Most relevant for the safety premium, they find that the nondefault component is about 50 basis points for Aaa- and Aa-rated bonds and about 70 basis points for lower-rated bonds. Thus the premium due to safety for the Aaa bond is 20 basis points, which is similar to our estimate of 27 basis points.

\section{Conclusion}

Investors value the liquidity and safety attributes of Treasuries. We document this by showing that changes in Treasury supply have large effects on a variety of yield spreads. Evaluated on the basis of the Baa-Treasury spread (for long-term bonds), a one-standard-deviation reduction in Treasury supply (starting from mean supply) lowers Treasury yields by 77 basis points relative to corporate bond yields. The effects based on the CPP2-bills spread (for short-term bonds) have roughly similar magnitudes.

By studying pairs of assets with similar liquidity but different safety (higher- and lower-grade corporate bonds and commercial paper) or

\footnotetext{
${ }^{12}$ It is a coincidence that the 1.44 percent price premium and the 144 basis point convenience yield are the same numbers in the example. For the sample studied in Krishnamurthy (2002) for 1990-99, the paper finds that the on-the-run/off-the-run yield spread converges at the rate of 3.2 basis points per 90 days (table 6 , col. 1), which translates to an annualized liquidity convenience yield of 156 basis points $(=12 \times 3.2 \times$ $[365 / 90])$.

${ }^{13}$ In the piecewise-linear regressions, the constant term $b_{0}$ is the average default component of the spread, since the EDF, volatility, and slope controls in the regressions are demeaned. Consider col. 4 for the Baa-Treasury spread. This regression indicates that $b_{0}$ is 1.200 , which is within the range of estimates from the corporate bond price literature of the default component of Baa bonds (see Longstaff et al. 2005).
} 
with similar safety but different liquidity (FDIC-insured CDs and Treasury bills), we document that changes in Treasury supply drive both the equilibrium price of safety and the equilibrium price of liquidity. This implies that Treasuries carry both a safety and a liquidity attribute. Using a piecewise-linear specification, we estimate that the average convenience yield on long-term Treasuries over the period 1926-2008 is 73 basis points, of which at most 46 basis points are driven by the liquidity of Treasuries and at least 27 basis points by the safety of Treasuries.

One way of putting these basis point estimates in perspective is to compute the seigniorage the government collects from being able to finance the US federal debt with securities that offer convenience benefits. The historical average debt-to-GDP ratio is 0.439 . At this debt-toGDP, the convenience yield from the Baa-Treasury piecewise linear specification in column 4 of table 3 evaluates to 53 basis points. Multiplying these numbers together gives seigniorage of 0.23 percent of GDP. Alternatively, if we evaluate the convenience yield at each of the debt-toGDP ratios in our sample, multiplying by that debt-to-GDP ratio and then averaging, we find that average seigniorage is also 0.23 percent of GDP. ${ }^{14}$ For comparison, consider the seigniorage that the government derives from households' willingness to hold fiat money at no interest. The monetary base at the end of 2007, prior to the Federal Reserve's quantitative easing experiment, was $\$ 825$ billion, corresponding to 6 percent of GDP. Suppose that the federal government had to repurchase the monetary base by issuing Treasury bills and that these Treasury bills had a 4 percent nominal yield. Then the annual interest expense of this additional debt would be $4 \times 0.06=0.24$ percent of GDP per year. Together, these calculations suggest that the total benefit from the convenience yield on Treasuries is large and that the seigniorage to the government from being able to finance the current level of debt with securities that have a convenience yield has the same order of magnitude as the seigniorage resulting from the public's willingness to hold fiat money at no interest.

Our results have many implications for asset pricing. Since Treasury debt carries a convenience yield, the common practice of identifying the Treasury interest rate with models' riskless interest rate is incorrect. We have argued that the observed price of a one-period Treasury is $P_{t}^{T}=E_{t}\left[M_{t+1}\right] /\left[1-v^{\prime}\left(\theta_{t}^{A} / \mathrm{GDP}_{t} ; \xi_{t}\right)\right]$ (implying an interest rate of $i_{t}^{T} \approx$ $\left.-\ln E_{t}\left[M_{t+1}\right]-v^{\prime}(\cdot)\right)$. The Treasury interest rate is lower than the "true" riskless interest rate. In order to recover the true riskless rate from the

\footnotetext{
14 These computations implicitly assume that the convenience yield for short Treasuries is similar to that for long Treasuries. Owing to the wartime interventions noted above, we cannot estimate the level of the convenience yield for short Treasuries using the kinked specification. However, we found quite similar sensitivity of long and short spreads to changes in debt/GDP in table 1, suggesting that this may be a reasonable assumption.
} 
data (the rate that can meaningfully be compared to the riskless rate from a model that ignores the convenience benefits of Treasuries), one has to estimate the convenience yield and adjust Treasury rates by this convenience yield. Our estimated demand curves may be used to measure the convenience yield and make the adjustment. The literature has found that the high spread between corporate bond rates and Treasury rates, and the high equity premium, measured as the average excess stock market return over Treasury bill rates, are hard to reconcile on the basis of standard factors. Accounting for a true riskless rate that is higher than the Treasury rate can go part of the way toward reconciling these findings.

\section{Appendix A}

\section{Derivation for Prediction 2}

We rewrite $(9)$, using the approximation that $1-v^{\prime}(\cdot) \approx e^{-v^{\prime}(\cdot)}$, so that the return from $t$ to $t+1$ on holding Treasury bonds satisfies

$$
\begin{aligned}
1 & =e^{v^{\prime}\left(\theta_{t}^{A} / \mathrm{GDP}_{t} ; \xi_{t}\right)} E_{t}\left[M_{t+1} P_{t+1}^{T} / P_{t}^{T}\right] \\
& =E_{t}\left[M_{t+1} e^{-(\tau-1) i_{t+1, \tau-1}^{T}+\tau i_{t, \tau}^{T}+v^{\prime}\left(\theta_{t}^{A} / \mathrm{GDP}_{t} \xi_{t}\right)}\right] .
\end{aligned}
$$

Likewise, for corporate bonds, rewriting (16), we find

$$
1=e^{-\lambda_{t} D_{t}} E_{t}\left[M_{t+1} P_{t+1}^{C} / P_{t}^{C}\right]=E_{t}\left[M_{t+1} e^{-(\tau-1) i_{t+1, \tau-1}^{C}+\tau i_{t, \tau}^{C} C_{t} D_{t}}\right] .
$$

The excess return on corporate bonds over Treasury bonds is

$$
R_{t+1}=\frac{P_{t+1}^{C}}{P_{t}^{C}}-\frac{P_{t+1}^{T}}{P_{t}^{T}} \approx-(\tau-1) S_{t+1, \tau-1}+\tau S_{t, \tau} .
$$

We log-linearize to make the approximation. We make the following computations to arrive at an expression for the spread $S_{t, \tau}$. We assume that $M_{t+1}$ is lognormally distributed (where $m \equiv \ln M$ ) and that all interest rates are normally distributed. Then, it is straightforward to rewrite (A1) as

$$
\begin{aligned}
1= & \exp \left\{v^{\prime}\left(\theta_{t}^{A} / \operatorname{GDP}_{t} ; \xi_{t}\right)+E_{t}\left[m_{t+1}\right]+\frac{1}{2} \operatorname{Var}_{t}\left(m_{t+1}\right)-(\tau-1) E_{t}\left[i_{t+1, \tau-1}^{T}\right]\right. \\
& \left.+\tau i_{t, \tau}^{T}+\frac{1}{2}(\tau-1)^{2} \operatorname{Var}_{t}\left(i_{t+1, \tau-1}^{T}\right)-\operatorname{Cov}_{t}\left[m_{t+1},(\tau-1) i_{t+1, \tau-1}^{T}-\tau i_{t, \tau}^{T}\right]\right\}
\end{aligned}
$$

and rewrite (A2) as

$$
\begin{aligned}
1= & \exp \left\{-\lambda_{t} D_{t}+E\left[m_{t+1}\right]+\frac{1}{2} \operatorname{Var}\left(m_{t+1}\right)-(\tau-1) E_{t}\left[i_{t+1, \tau-1}^{C}\right]\right. \\
& \left.+\tau i_{t, \tau}^{C}+\frac{1}{2}(\tau-1)^{2} \operatorname{Var}_{t}\left(i_{t+1, \tau-1}^{C}\right)-\operatorname{Cov}\left[m_{t+1},(\tau-1) i_{t+1, \tau-1}^{C}-\tau i_{t, \tau}^{C}\right]\right\} .
\end{aligned}
$$

We take logs and subtract these last two equations. We assume that the terms involving $\operatorname{Var}_{t}\left(i_{t+1, \tau-1}^{T}\right)$ and $\operatorname{Var}_{t}\left(i_{t+1, \tau-1}^{C}\right)$ are approximately the same. That is, innovations in both corporate and Treasury rates have the same variance. Then 


$$
\begin{aligned}
0= & \frac{1}{\tau}\left[v^{\prime}\left(\theta_{t}^{A} / \operatorname{GDP}_{t} ; \xi_{t}\right)+\lambda_{t} D_{t}\right]+\frac{\tau-1}{\tau} E_{t}\left[S_{t+1, \tau-1}\right] \\
& -S_{t, \tau}+\frac{1}{\tau} \operatorname{Cov}_{t}\left[m_{t+1},(\tau-1) S_{t+1, \tau-1}-\tau S_{t, \tau}\right],
\end{aligned}
$$

or

$$
S_{t, \tau}=\frac{1}{\tau}\left[v^{\prime}\left(\theta_{t}^{A} / \mathrm{GDP}_{t} ; \xi_{t}\right)+\lambda_{t} D_{t}\right]+\frac{\tau-1}{\tau} E_{t}\left[S_{t+1, \tau-1}\right]-\frac{1}{\tau} \operatorname{Cov}_{t}\left(m_{t+1}, R_{t+1}\right) .
$$

Solving this equation recursively for $S_{t, \tau}$, we find the expression in the text.

\section{Appendix B}

\section{Data}

For all yield spreads analyzed in table 1, table 2, panel A, and table 3, we use annual observations, sampled in July of the year up to (and including) 1976 and in October of each year after that.

\section{Table 1}

Aaa-Treasury yield spread: The percentage spread between Moody's Aaa-rated long-maturity corporate bond yield and the yield on long-maturity Treasury bonds. The Moody's Aaa index is constructed from a sample of long-maturity ( $\geq 20$ years) industrial and utility bonds (industrial only from 2002 onward), available from 1919 to 2008 . The yield on long-maturity Treasury bonds is the average yield on long-term government bonds, available from 1919 to 1999 . The Treasury bonds included are due or callable after 8 years for 1919-25, 12 years for 1926-41, 15 years for 1941-51, 12 years for 1952, and 10 years for 1953-99. We use the yield on 20-year maturity Treasury bonds for 2000-2008. All three data series are from the Federal Reserve's FRED database (series AAA, LTGOVTBD, and GS20), with the exception that the long-term Treasury yield data for 1919-24 are from Banking and Monetary Statistics, 1914-41, table 128.

Baa-Treasury yield spread: The percentage spread between Moody's Baa-rated long-maturity corporate bond yield and the yield on long-maturity Treasury bonds. The Moody's Baa index is constructed from a sample of long-maturity ( $\geq 20$ years) industrial and utility bonds (industrial only from 2002 onward), available from 1919 to 2008 . The Baa data series is also from the FRED database (series BAA).

CP-bills yield spread: The percentage yield spread between high-grade commercial paper and Treasury bills. For 1971-2008 the commercial paper yield is from the FRED database. For 1971-96 it is the series CP3M (the average of offering rates on 3-month commercial paper placed by several leading dealers for firms whose bond rating is AA or equivalent), and for 1997-2008 the series CPN3M (the 3-month AA nonfinancial commercial paper rate). Prior to 1971 we use the commercial paper series for prime commercial paper, 4-6-month maturity, from Banking and Monetary Statistics (table 12.5 for 1941-70 and table 120 for 1920-40). The Treasury bill yield is for 3-month Treasury bills for 1971- 
2008 (from FRED, series TB3MS), 6-month Treasury bills for 1959-70 (from FRED, series TB6MS), and 3-6 month Treasury bills for 1920-58 from the NBER Macro History database (series m13029b for 1931-58 and series m13029a for 1920-30).

CPP2-bills yield spread: The percentage yield spread between lower-grade commercial paper and Treasury bills. Calculated as the sum of the CP-bills yield spread described above (i.e., high-grade commercial paper minus Treasury bills) and the yield spread between 30-day A2/P2 nonfinancial commercial paper and 30-day AA nonfinancial commercial paper, with data obtained from the Federal Reserve Bank of New York. ${ }^{15}$ For 1996 and 1997 we do not have data from the Federal Reserve and use data from Bloomberg (Bloomberg currently does not have data for these two years, and our data are based on an earlier download from Bloomberg).

Debt/GDP: The supply of Treasuries scaled by GDP, at market value. Calculated as (debt/GDP with debt at face value) $\times$ (total market value of Treasuries/total face value of Treasuries).

The debt/GDP series (with debt at face value) is from Henning Bohn's web page for years 1919-2008. The debt measure includes debt held by the Federal Reserve but excludes debt held by other parts of the government such as the Social Security Trust Fund. Debt is for the end of the government's fiscal year, that is, the end of June up to and including 1976 and the end of September from 1977 on. GDP is for the same fiscal year.

The Center for Research in Security Prices (CRSP) Monthly US Treasury Database is used to calculate the factor for translating face values to market values (total market value of Treasuries/total face value of Treasuries). This database starts in December 1925. Prior to 1949 the amounts outstanding are missing for a lot of the Treasuries. From 1949 onward, at least 96 percent of Treasuries in the database have values for amounts outstanding. We multiply Bohn's debt/GDP series by the CRSP ratio of Treasury market to face value to get a series for the market value of Treasury debt/GDP. Over the period 19492008, the correlation between debt/GDP at face value and debt/GDP at market value is .996 , and the means and standard deviations of the two series are very similar. Prior to 1949, one can still calculate the ratio of Treasury market to face value for the set bonds in the CRSP database for which the data are available. This set is somewhat skewed toward better coverage of long maturities. We get similar results whether we use debt/GDP at face value and debt/GDP at market value in the pre-1949 period. We report the results that use the market debt/ GDP series.

Prior to 1926 the CRSP database is not available, and we therefore do not make the market value adjustment. In general, over the 1926-2008 period our results throughout the paper are very similar whether the market value adjustment is made or not.

Volatility: Annualized standard deviation of weekly log stock returns on the S\&P 500 index. We calculate weekly returns on the value-weighted S\&P index on the basis of daily returns obtained from CRSP. As the volatility measure for a given year, we compute the standard deviation of the weekly log returns over

${ }^{15}$ We thank Kenneth Kuttner and Michael Fleming for help in obtaining these data. 
the year leading up to the end of the government's fiscal year. We annualize the standard deviation of weekly log returns by multiplying by the square root of 52 .

$E D F$ : Expected default frequency for nonfinancial corporate bonds. The data are obtained from Moody's Analytics. We use the median EDF credit measure reported by Moody's Analytics for large nonfinancial firms (defined as firms with a book value of assets $>\$ 300$ million in inflation-adjusted dollars). The EDF credit measure is available from 1969 to 2008. We use annual observations, sampled in July of the year up to (and including) 1976 and in October of each year after that.

Slope: Slope of the Treasury yield curve measured as the spread between the 10-year Treasury yield and the 3-month Treasury yield. The interest rate on Treasuries with 10-year maturity is from FRED for 1953-2008 (series GS10). Prior to 1953 we use series m13033a (1926-41) and m13033b (1942-52) from the NBER Macro History Database, with both these series referring to the yield on long-term Treasuries. The interest rate on Treasuries with 3-month maturity is from FRED for 1934-2008 (series TB3MS) and from the NBER Macro History database prior to that (series m13029a for 1926-33, referring to 3-6-month Treasuries). We use annual observations, sampled in July of the year up to (and including) 1976 and in October of each year after that.

In all tables, volatility, EDF and slope variables are demeaned.

\section{Table 2, Panel A}

Baa-Aaa yield spread: The percentage yield spread between Moody's Baa-rated long-maturity bond yield and Moody's Aaa-rated long-maturity bond yield. Both series are described under table 1 above.

A2/P2-A1/P1 yield spread: The yield spread between 30-day A2/P2 nonfinancial commercial paper and 30-day AA nonfinancial commercial paper, with data obtained from the Federal Reserve Bank of New York and Bloomberg (as described under table 1).

(Debt $>10$ year maturity)/GDP: The ratio of Treasury debt with more than 10 years' remaining maturity to GDP. For 1949-2008 the amount of Treasury debt is at market value and is calculated using the CRSP Monthly US Treasury Database. For 1926-48 the amount of Treasury debt is at face value and is obtained from Banking and Monetary Statistics 1914-41, table 147, and Banking and Monetary Statistics 1941-70 (table 13.5A minus table 13.5B).

(Debt $\leq 1$ year maturity) /GDP: The ratio of Treasury debt with a year or less of remaining maturity to GDP. For 1949-2008 the amount of Treasury debt is at market value and is calculated using the CRSP Monthly US Treasury Database (we use this series only in col. 2, which is based on data from 1974 onward).

For the above two variables, the data for GDP used are from Henning Bohn's web page.

Debt/GDP, volatility, slope: As for table 1. 
Table 2, Panel B

(FDIC-insured CDs)-bills yield spread: The percentage yield spread between the yield on 6-month certificates of deposit and Treasury bills. The CD yields are the national average rates obtainable by depositors on small-denomination (and thus FDIC-insured) CDs of 6-month maturity, where small denomination means the account opening minimum. The rates are from Bank Rate Monitor and are obtained from the New York Times for 1984-97 and from Bloomberg for 19982008 (ticker ILSFNAVG) and are as of the end of September. The Treasury bill yield used is the yield on 6-month bills obtained from FRED (series TB6MS), as of September.

(Time and savings accounts)-bills yield spread: The percentage yield spread between time and savings accounts and Treasury bills. We estimate the yield on time and savings accounts using data from FDIC Historical Statistics on Banking, tables CB06 and CB15. Specifically, we divide the total annual interest on deposits in domestic offices by the sum of savings and time deposits in domestic offices (using averages of beginning- and end-of-year values for the deposits). The FDIC series is available from 1935 onward. We compare this yield series to the yield on 6-month Treasuries, with data obtained from FRED (series TB6MS) from 1959 on and from the NBER Macro History database prior to that (series m13029b for 1935-58, referring to 3-6-month Treasuries). Since the yield on time and savings accounts is an annual average, we use the annual calendar year average of 6-month monthly Treasury bill rates for comparison.

Slope: Slope of the Treasury yield curve measured as the spread between the 10-year Treasury yield and the 6-month Treasury yield. The interest rate on Treasuries with 10-year maturity is defined as in the slope variable used in table 1. The interest rate on Treasuries with 6-month maturity is from FRED for 19592008 (series TB6MS) and from the NBER Macro History database prior to that (series m13029b, referring to 3-6-month Treasuries). The slope variable in column 5 is based on September values to match the timing of the left-hand-side variable. The slope variable in column 6 is (annual calendar year average of 10year monthly yields) - (annual calendar year average of 6-month monthly yields), in order to match the timing of the dependent variable, which is a calendar year average.

Debt/GDP: As for table 1.

Table 3: Same data as for table 1.

\section{References}

Amihud, Yakov, and Haim Mendelson. 1991. "Liquidity, Maturity, and the Yields on U.S. Treasury Securities." J. Finance 46 (September): 31-53.

$\rightarrow$ Bansal, Ravi, and John Wilbur Coleman II. 1996. "A Monetary Explanation of the Equity Premium, Term Premium, and Risk-Free Rate Puzzles." J.P.E. 104 (December): 1135-71.

$\rightarrow$ Barro, Robert J. 1974. “Are Government Bonds Net Wealth?” J.P.E. 82 (December): 1095-1117.

$\rightarrow$ Chalmers, John M. 1998. "Default Risk Cannot Explain the Muni Puzzle: Evidence from Municipal Bonds That Are Secured by U.S. Treasury Obligations.” Rev. Financial Studies 11 (April): 281-308. 
$\rightarrow$ Chen, Long, David Lesmond, and Jason Wei. 2007. "Corporate Yield Spreads and Bond Liquidity." J. Finance 62 (February): 119-49.

Cortes, Fabio. 2003. "Understanding and Modelling Swap Spreads." Bank of England Q. Bull. 43 (Winter): 407-16

$\rightarrow$ Covitz, Dan, and Chris Downing. 2007. "Liquidity or Credit Risk? The Determinants of Very Short-Term Corporate Yield Spreads." J. Finance 62 (May): 2303-28.

$\rightarrow$ Doepke, Matthias, and Martin Schneider. 2006. "Inflation and the Redistribution of Nominal Wealth.” J.P.E. 114 (December): 1069-97.

$\rightarrow$ Duffee, Gregory R. 1998. "The Relation between Treasury Yields and Corporate Bond Yield Spreads." J. Finance 53 (December): 2225-41.

$\rightarrow$ Duffie, Darrell, and Kenneth J. Singleton. 1999. "Modeling Term Structures of Defaultable Bonds." Rev. Financial Studies 12 (October): 687-720.

Elmendorf, Douglas W., and N. Gregory Mankiw. 1999. "Government Debt." In Handbook of Macroeconomics, edited by John B. Taylor and Michael Woodford, chap. 25. Amsterdam: Elsevier Sci.

FDIC (Federal Deposit Insurance Corporation). 1984. The First Fifty Years: A History of the FDIC, 1933-1983. Washington, DC: FDIC.

Gilbert, R. Alton. 1986. "Requiem for Regulation Q: What It Did and Why It Passed Away." Fed. Reserve Bank St. Louis Rev. 68 (February): 22-37.

$\rightarrow$ Gomes, Francisco, and Alexander Michaelides. 2008. "Asset Pricing with Limited Risk Sharing and Heterogeneous Agents." Rev. Financial Studies 21 (January): 415-48.

Gorton, Gary. 2010. Slapped by the Invisible Hand: The Panic of 2007. Oxford: Oxford Univ. Press.

Greenwood, Robin, and Dimitri Vayanos. 2010. "Bond Supply and Excess Bond Returns." Working paper, Harvard Bus. School.

$\rightarrow$ Krishnamurthy, Arvind. 2002. "The Bond/Old-Bond Spread." J. Financial Econ. 66 (December): 463-506.

$\rightarrow$ Krishnamurthy, Arvind, and Annette Vissing-Jorgensen. 2011. "The Effects of Quantitative Easing on Interest Rates: Channels and Implications for Policy." Brookings Papers Econ. Activity 2011 (Fall): 215-65.

$\rightarrow$ Longstaff, Francis. 2004. "The Flight-to-Liquidity Premium in U.S. Treasury Bond Prices.” J. Bus. 77 (July): 511-26.

$\rightarrow$ Longstaff, Francis, Sanjay Mithal, and Eric Neis. 2005. "Corporate Yields Spreads: Default Risk or Liquidity? New Evidence from the Credit-Default Swap Market." J. Finance 60 (October): 2213-53.

$\rightarrow$ Merton, Robert. 1974. "On the Pricing of Corporate Debt: The Risk Structure of Interest Rates.” J. Finance 29 (May): 449-70.

$\rightarrow$ Modigliani, Franco, and Richard Sutch. 1966. "Innovations in Interest Rate Policy.” A.E.R. Papers and Proc. 56 (May): 178-97.

Moody's Investors Service. 2000. "Commercial Paper Defaults and Rating Transitions, 1972-2000.” Moody's Investors Service, New York.

- 2005. "Default and Recovery Rates of Corporate Bond Issuers, 19202004." Moody's Investors Service, New York.

$\rightarrow$ Reinhart, Vincent, and Brian P. Sack. 2000. "The Economic Consequences of Disappearing Government Debt.” Brookings Papers Econ. Activity 2000 (Fall): 163-220.

Rocheteau, Guillaume. 2009. “A Monetary Approach to Asset Liquidity.” Working paper, Univ. California, Irvine.

$\rightarrow$ Sidrauski, Miguel. 1967. "Rational Choice and Patterns of Growth in a Monetary Economy.” A.E.R. Papers and Proc. 57 (May): 534-44. 
$\rightarrow$ Vayanos, Dimitri, and Jean-Luc Vila. 1999. "Equilibrium Interest Rate and Liquidity Premium with Transaction Costs." Econ. Theory 13 (May): 509-39.

$\rightarrow$ Vissing-Jorgensen, Annette. 2003. "Perspectives on Behavioral Finance: Does 'Irrationality' Disappear with Wealth? Evidence from Expectations and Actions." NBER Macroeconomics Ann. 18:139-208.

$\rightarrow$ Wicker, Elmus. 1969. "World War II Policy of Fixing a Pattern of Interest Rates." J. Finance 24 (June): 447-58. 